OPEN ACCESS

Edited by:

Dominic C. Voon,

Kanazawa University, Japan

Reviewed by:

Vladimir N. Uversky,

University of South Florida,

United States

Jormay Lim,

National Taiwan University, Taiwan

*Correspondence:

Emmanuel S. Tzanakakis

Emmanuel.Tzanakakis@tufts.edu

Specialty section:

This article was submitted to

Cell Growth and Division,

a section of the journal

Frontiers in Cell and Developmental

Biology

Received: 19 July 2019

Accepted: 30 September 2019

Published: 22 October 2019

Citation:

Chen Z, Downing $S$ and Tzanakakis ES (2019) Four Decades After the Discovery of Regenerating Islet-Derived (Reg) Proteins: Current

Understanding and Challenges.

Front. Cell Dev. Biol. 7:235.

doi: 10.3389/fcell.2019.00235

\section{Four Decades After the Discovery of Regenerating Islet-Derived (Reg) Proteins: Current Understanding and Challenges}

\author{
Zijing Chen ${ }^{1}$, Shawna Downing ${ }^{2}$ and Emmanuel S. Tzanakakis ${ }^{1,2 *}$ \\ ${ }^{1}$ Department of Chemical and Biological Engineering, Tufts University, Medford, MA, United States, ${ }^{2}$ Clinical \\ and Translational Science Institute, Tufts Medical Center, Boston, MA, United States
}

Regenerating islet-derived (Reg) proteins have emerged as multifunctional agents with pro-proliferative, anti-apoptotic, differentiation-inducing and bactericidal properties. Over the last 40 years since first discovered, Reg proteins have been implicated in a gamut of maladies including diabetes, various types of cancer of the digestive tract, and Alzheimer disease. Surprisingly though, a consensus is still absent on the regulation of their expression, and molecular underpinning of their function. Here, we provide a critical appraisal of recent findings in the field of Reg protein biology. Specifically, the structural characteristics are reviewed particularly in connection with established or purported functions of different members of the Reg family. Moreover, Reg expression patterns in different tissues both under normal and pathophysiological conditions are summarized. Putative receptors and cascades reported to relay Reg signaling inciting cellular responses are presented aiming at a better appreciation of the biological activities of the distinct Reg moieties. Challenges are also discussed that have hampered thus far the rapid progress in this field such as the use of non-standard nomenclature for Reg molecules among various research groups, the existence of multiple Reg members with significant degree of homology and possibly compensatory modes of action, and the need for common assays with robust readouts of Reg activity. Coordinated research is warranted going forward, given that several research groups have independently linked Reg proteins to diseased states and raised the possibility that these biomolecules can serve as therapeutic targets and biomarkers.

Keywords: Reg proteins, pancreas, diabetes, pancreatic adenocarcinoma, gastrointestinal cancer

\section{INTRODUCTION}

Since their discovery four decades ago, regenerating-islet derived (Reg) gene proteins have been linked to diverse pathologies including pancreatic ductal adenocarcinoma (PDAC), calcifying pancreatitis (De Caro et al., 1979), diabetes (Graf et al., 2006; Parikh et al., 2012) and extrapancreatic maladies such as Alzheimer disease and cancers of the gastrointestinal (GI) tract. Surprisingly though, very little is known about the regulation of their expression, exact functional role(s), and underlying mechanism(s). Even a receptor of rat Reg1 identified (Kobayashi et al., 2000) as homologous to the human exostosin-like glycosyltransferase 3 (EXTL3) (Kim et al., 2001) is still 
described in relevant literature as putative and its cellular localization and signaling role(s) are debatable (Osman et al., 2003). Sporadic studies have implicated various moieties such as the mitogen-activated protein kinase (MAPK) phosphatase (MKP-1) and phosphoinositide 3-kinase (PI3K) (Kadowaki et al., 2002; Takasawa et al., 2006; Mueller et al., 2008) as transducers of Reg signaling, but these results have been inconclusive or even conflicting.

Yet, Reg proteins are emerging as multifunctional moieties. Several Reg family members have been shown to promote proliferation, differentiation, and prevent apoptosis in diverse cell types in different contexts. For instance, PDAC and diabetes patients have higher serum levels of REG1A compared to healthy subjects, and REG3A is also increased in ductal fluid (Astorri et al., 2010; Porterfield et al., 2014; Yang et al., 2015; Li et al., 2016b). REG4 is overexpressed in colorectal and gastric carcinomas (Violette et al., 2003; Oue et al., 2005) whereas REG3A is expressed in hepatocellular carcinomas with $\beta$-catenin mutations (Cavard et al., 2006). Additionally, Reg proteins (e.g., human REG3A and mouse Reg3g) act as antimicrobial peptides contributing to the regulation of gut microbiota (Vaishnava et al., 2011; Mukherjee et al., 2014). Such associations make more pressing the need for better understanding the biology of Reg proteins and defining their functional features. Progress in this direction however, has been hampered by the existence of multiple members in the Reg family making challenging to gain insights into Reg regulation and bioactivity. This is further exacerbated by the inconsistent nomenclature for Reg proteins adopted in the published literature (Parikh et al., 2012).

In this review, we discuss the structural characteristics of Reg proteins as they may permit to shine light on Reg activity. The involvement of Reg members is also surveyed, particularly in various diseases. Signaling networks evidenced to operate in conjunction with Reg are also reviewed. Lastly, challenges are presented regarding research aiming to advance our knowledge of the expression and function of Reg proteins.

\section{STRUCTURE OF Reg PROTEINS}

The Reg family comprises four groups (Reg1, Reg2, Reg3, and Reg4) of proteins based on their primary structure (Okamoto, 1999). Reg1 was discovered independently by various groups and reported under different names, such as lithostathine (due to the protein's presumed inhibitory role in pancreatic stone formation), pancreatic stone protein (PSP; partially hydrolyzed form of Reg1), P19 and pancreatic thread protein (PTP) (Gross et al., 1985; Terazono et al., 1988; Watanabe et al., 1990). The Reg1 mRNA encodes a 166-amino acid (aa) preprotein including a 22-aa $\mathrm{N}$-terminal signal sequence that is cleaved in the secreted protein (see below). Members of the first group are found in different species including humans and rodents. REG1A (also known as lithostathine) and REG1B are expressed in humans. The two proteins are $87 \%$ homologous to each other and exhibit a $72-74 \%$ similarity with the murine Reg1 (Figure 1).

The mouse Reg2 has the highest sequence similarity to Reg1 $(76 \%)$ whereas there is no human ortholog of Reg2.
The Reg3 group includes the rodent Reg3a (or Reg3 $\alpha$ ), Reg3b (or Reg3 $\beta$ ), Reg3g (or Reg3 $\gamma$ ), and Reg3d (or Reg38). In contrast, only REG3A (also reported as hepatocarcinoma-intestinepancreatic protein (HIP), pancreatitis-associated protein (PAP), and PAP1) and REG3G (also referred to as PAP1B) are expressed in human cells. REG3G is $65-66 \%$ homologous to the murine Reg3a, Reg3b and Reg3g. Analogously, REG3A is $62-67 \%$ similar to murine Reg3a and Reg3g, and 70\% to Reg3b.

The last Reg group, Reg4, contains only one member. REG4, which was discovered more recently (Hartupee et al., 2001), is expressed in rodents and humans and exhibits the lowest similarity with any of the other Reg proteins. Overall, five Reg members are expressed in humans: REG1A, REG1B, REG3A, REG3G, and REG4.

Given the high homology among various Reg genes, it is very likely that all originated from the same ancestral gene (Hartupee et al., 2001). All Reg genes are composed of six exons except from the Reg4 gene which consists of seven exons. In fact, all human Reg genes are located on the second chromosome (2p12) whereas the gene for Reg4 is on chromosome 1 (1p11$3)$. In mice, the Reg1-3 groups are clustered on chromosome $6 \mathrm{C} 3$ and Reg4 is located on 3F3. The genes span two to three kilobases in length (Hartupee et al., 2001).

Perhaps the most distinctive feature of Reg proteins is the C-type-like lectin domain (CTLD), which selectively binds a wide variety of ligands and carbohydrates (Dieckgraefe et al., 2002). Typically, $\mathrm{Ca}^{2+}$ mediates many CTLD interactions including binding to glycans. In other instances, $\mathrm{Ca}^{2+}$ causes a functional transformation of CTLD without binding carbohydrates. For example, the binding of $\mathrm{Ca}^{2+}$ to the CTLD of human tetranectin inhibits the protein's interaction with plasminogen (Graversen et al., 1998). Based on structural analysis however, no Reg member contains a characteristic $\mathrm{Ca}^{2+}$-binding motif (Zelensky and Gready, 2005). Yet, Lee et al. (2003) reported the 1:1 binding of $\mathrm{Ca}^{2+}$ to recombinant human lithostathine produced in E. coli (thus, not being glycosylated; see below about Reg glycosylation). This interaction was attributed to the presence on the lithostathine surface of anionic residues (E30, D31, E33, D37, D72, and D73) and their mutation resulted in the significant decrease or loss of sugar binding affinity. Other Reg members are reported to bind carbohydrates in a $\mathrm{Ca}^{2+}$. independent manner. The human REG4 binds to mannan with two $\mathrm{Ca}^{2+}$-independent sites (Figure 2) (Ho et al., 2010). It also binds to heparin but not glucose, mannose and galactose (Ho et al., 2010). REG3A (HIP/PAP) also recognizes peptidoglycan through an 114-EPN-116 motif while a E114Q mutation weakens drastically this interaction (Lehotzky et al., 2010) (Figure 2). The same mutation reduces the bactericidal effect of REG3A against L. monocytogenes suggesting that REG3A selectively binds to bacterial cell surface sugars. Binding affinity increases with the length of the carbohydrate moiety, which is the principal factor (as opposed to the peptide sequence) dictating the REG3A/sugar interaction. This suggests that Reg combines selectively with peptidoglycans on the bacterial cell wall despite the presence of soluble peptidoglycan fragments. Like the REG3A, the murine Reg3g and Reg $3 \mathrm{~b}$ also feature the EPN motif and thus bind to peptidoglycan, chitin and mannan but not to dextran 
A

\begin{tabular}{|c|c|c|c|c|c|}
\hline & $\begin{array}{r}\text { REG1A } \\
\text { (P05451) }\end{array}$ & $\begin{array}{l}\text { REG1B } \\
\text { (P48304) }\end{array}$ & $\begin{array}{l}\text { REG3A } \\
\text { (Q06141) }\end{array}$ & $\begin{array}{l}\text { REG3G } \\
\text { (Q6UW15) }\end{array}$ & $\begin{array}{c}\text { REG4 } \\
\text { (Q9BYZ) }\end{array}$ \\
\hline Reg1 (P43137) & $74.53 \%$ & $72.05 \%$ & $47.53 \%$ & $48.47 \%$ & $34.07 \%$ \\
\hline Reg2 (Q08731) & $65.12 \%$ & $63.37 \%$ & $42.61 \%$ & $40.68 \%$ & $32.59 \%$ \\
\hline Reg3a (009037) & $43.53 \%$ & $44.51 \%$ & $61.85 \%$ & $65.52 \%$ & $35.25 \%$ \\
\hline Reg3b (P35230) & $41.72 \%$ & $42.28 \%$ & $69.54 \%$ & $68.79 \%$ & $31.88 \%$ \\
\hline Reg3g (009049) & $44.87 \%$ & $44 \%$ & $67.05 \%$ & $64.94 \%$ & $36.23 \%$ \\
\hline Reg3d (Q9QUS9) & $43.29 \%$ & $44.85 \%$ & $49.71 \%$ & $51.15 \%$ & $26.62 \%$ \\
\hline Reg4 (Q9D8G5) & $32.69 \%$ & $33.97 \%$ & $35.03 \%$ & $32.28 \%$ & $66.24 \%$ \\
\hline
\end{tabular}

B

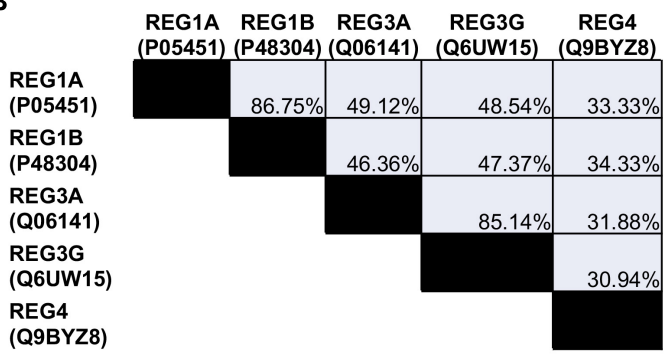

C

\begin{tabular}{|c|c|c|c|c|c|c|c|}
\hline & $\begin{array}{c}\text { Reg1 } \\
\text { (P43137) }\end{array}$ & $\begin{array}{c}\text { Reg2 } \\
(\mathrm{Q} 08731)\end{array}$ & $\begin{array}{c}\text { Reg3a } \\
(009037)\end{array}$ & $\begin{array}{c}\text { Reg3b } \\
(\text { P35230) }\end{array}$ & $\begin{array}{c}\text { Reg3g } \\
(009049)\end{array}$ & $\begin{array}{c}\text { Reg3d } \\
\text { (Q9QUS9) }\end{array}$ & $\begin{array}{c}\text { Reg4 } \\
\text { (Q9D8G5) }\end{array}$ \\
\hline Reg1 (P43137) & & $75.74 \%$ & $41.10 \%$ & \begin{tabular}{|l|l|} 
& $41.06 \%$ \\
\end{tabular} & $46 \%$ & $42.42 \%$ & $31.37 \%$ \\
\hline Reg2 (Q08731) & & & $39.55 \%$ & $\begin{array}{ll} & 40.26 \% \\
\end{array}$ & $41.22 \%$ & $40.94 \%$ & $27.59 \%$ \\
\hline Reg3a (009037) & & & & $59.54 \%$ & $58.62 \%$ & $50 \%$ & $33.54 \%$ \\
\hline Reg3b (P35230) & & & & & $71.68 \%$ & $54.22 \%$ & $36.88 \%$ \\
\hline Reg3g (009049) & & & & & & $50 \%$ & $35.85 \%$ \\
\hline Reg3d (Q9QUS9) & & & & & & & $27.85 \%$ \\
\hline g4 (Q9D8G5) & & & & & & & \\
\hline
\end{tabular}

FIGURE 1 Amino acid sequence homology of the (A) human vs. the mouse Reg proteins, (B) human, and (C) mouse Reg proteins to each other. The numbers in parentheses refer to the individual protein entry ID in the UniProt database (http://www.uniprot.org). When multiple IDs are available for a protein, an ID is selected corresponding to an entry that has undergone review. Homology between sequences was quantified with the NCBI protein BLAST tool

(https://blast.ncbi.nlm.nih.gov).

A

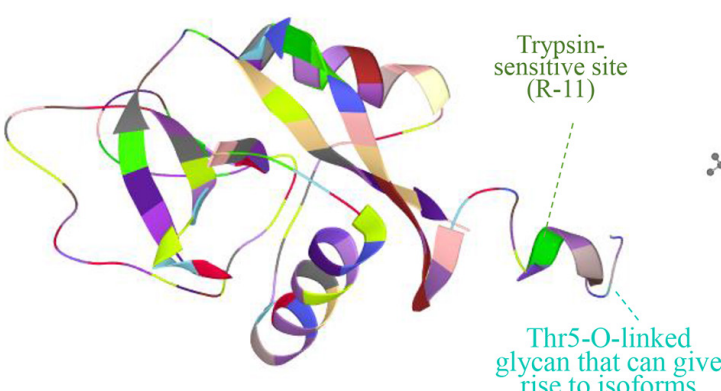

rise to isoforms

B

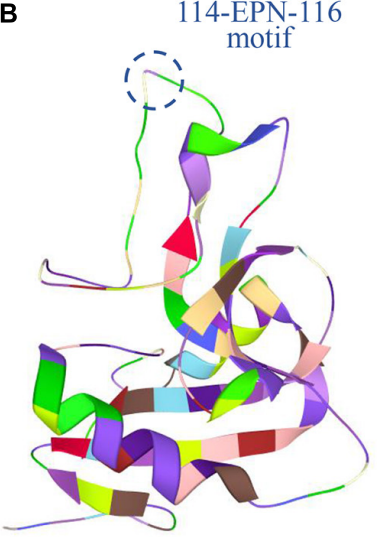

114-EPN-116

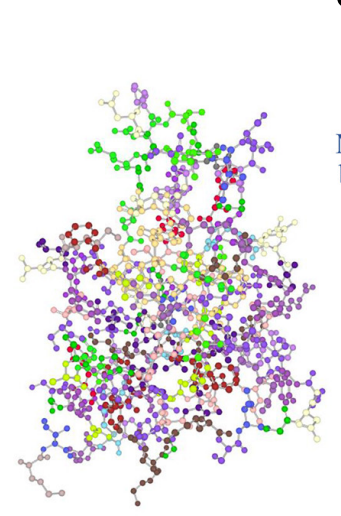

C

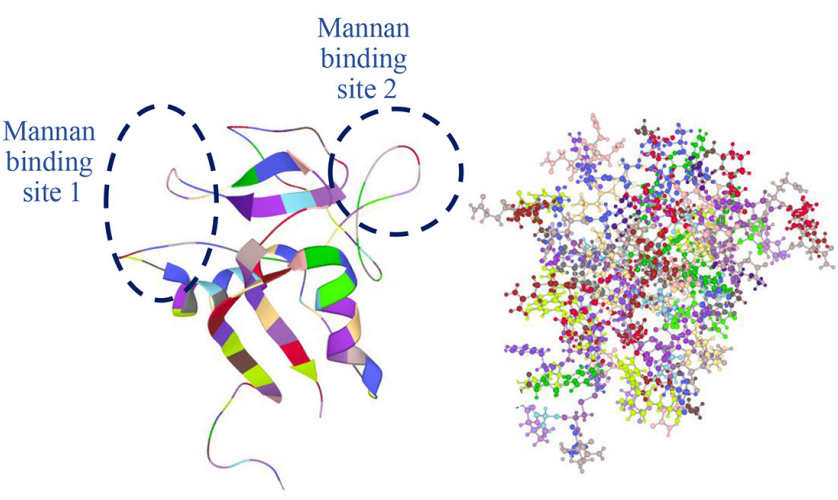

FIGURE 2 | Protein structures obtained from the Protein Data Bank (PDB: https://www.rcsb.org/) are shown in figures of ribbon and ball and stick (colored by residues) of the human (A) REG1A (PDB ID: 1QDD, Gerbaud et al., 2000), (B) REG3A (PDB ID: 4MTH, Mukherjee et al., 2014), and (C) REG4 (PDB ID: 2KV3, Ho et al., 2010). In REG1A, the signal peptide is 22-aa long shortening the protein chain from 166 to 144 aa with a trypsin-sensitive arginine at position 11 (R-11) (De Reggi and Gharib, 2001). A Thr5-O-linked glycan is also featured that gives rise to different isoforms (De Reggi et al., 1995). REG3A (HIP/PAP) recognizes peptidoglycan carbohydrate backbones through an 114-EPN-116 motif that confers bactericidal activity while a E114Q mutation weakens this interaction (Lehotzky et al., 2010). REG4 has a C-type like domain (CTLD) and two calcium-independent sites that bind mannan (Ho et al., 2010). Images were created in LiteMol Suite (Sehnal et al., 2017). 
(Cash et al., 2006). In contrast, the murine Reg3a lacks this domain and does not bind peptidoglycan. It is plausible that Reg binding to sugars without calcium may serve the purpose of maintaining the carbohydrate recognition interaction in the low-pH milieu of the GI tract. Along similar lines, various Reg members (e.g., REG3A, Reg1, Reg3g) are reportedly involved in the agglutination of bacteria (Iovanna et al., 1993; Cash et al., 2006). Such function may serve to control microbiota during inflammation (Ogawa et al., 2003; Keilbaugh et al., 2005). Whether the presence of CTLD (i) imparts functional attributes to Reg proteins besides their bactericidal activity, and (ii) contributes to potential interactions with other molecules remain open questions.

The human lithostathine has a Thr5-O-linked glycan that gives rise to different isoforms (Figure 2). De Reggi et al. (1995) determined the sequence of seven lithostathine glycoforms out of 11 isolated. The glycoforms contain the same core structure $\operatorname{GlcNAc}(\beta 1-6)[\operatorname{Gal}(\beta 1-3)]$ GalNAc $\alpha$ - with extensions of variable length. The importance of this diversity in glycosylated forms is unclear but the glycan chain is postulated to aid the stability of the protein and be involved in the localization of Reg protein.

A feature of Reg proteins is a cleavage site for trypsin near the N-terminus proceeded by a putative signal peptide. In human REG1A the signal peptide is 22 aa long shortening the protein chain from 166 aa to 144 aa with a trypsin-sensitive arginine at position 11 (Figure 2A) (De Reggi and Gharib, 2001). The cleavage site is displayed by most Reg protein members expressed in rodents and humans. Trypsin digestion results in a soluble short peptide and the remaining insoluble fragment of over 130 residues that forms fibrils resistant to further digestion by pancreatic proteases (except for rat PAP II/Reg3a which does not form insoluble precipitates and is digested by proteases after trypsin activation) (Graf et al., 2001). The latter resembles the action of pancreatic zymogens, which become active upon cleavage of a peptide sequence although the physiological role of formation of Reg fibrils remains unclear. The presence of these structures has been documented in pancreatic stones of patients with chronic pancreatitis. It was hypothesized that cleaved Reg protein forms plugs in the biliary tract after regurgitation of pancreatic juice with activated trypsin being present. In support of this hypothesis, cleaved Reg (PSP), trypsinogen and activated trypsin were detected in the bile-duct bile and the gallbladder bile of the patients but were absent in those of the controls (Ochiai et al., 2004). Interestingly, there was no evidence of the presence of Reg in the aforementioned plugs of patients with pancreaticobiliary maljunction, and the PSP concentration in the patients' bile was three orders of magnitude lower than in the pancreatic juice under normal conditions. Human REG3A also assembles into filaments in the gut with a possible bacteriostatic role but the process requires the presence of cell membranes (Mukherjee et al., 2014).

It should be noted that lithostathine forms fibrils at neutral $\mathrm{pH}$ by undergoing autolytic cleavage via a yet poorly understood mechanism (Cerini et al., 1999). Parallels have been drawn between this process and the formation of Alzheimer plaques consisting of $\beta$-amyloid fibers as a result of the self-assembly of protein oligomers (De Reggi and Gharib, 2001). However, unlike typical amyloid fibrils, which have a cross- $\beta$-sheet structure, Reg fibrils display a secondary structure similar to that of the native protein (two $\alpha$-helices and eight $\beta$-strands) (Ho et al., 2006). Nonetheless, PTP (lithostathine)-reactive brain lesions and elevated PTP expression are observed in Alzheimer patients (Ozturk et al., 1989; de la Monte et al., 1990). In fact, both lithostathine and PAP (Reg3) are present in senile plaques and neurofibrillary tangles of patients with Alzheimer disease (Duplan et al., 2001). The physiological role of Reg proteins in the disease remains elusive. Reg expression in the brain may be upregulated by inflammation similar to Reg mRNA induction with acute pancreatitis (Dusetti et al., 1996a). Increased Reg expression may lead to autolysis of the protein and formation of fibrils exacerbating the precipitation of $\beta$-amyloid peptides at the early stages of Alzheimer disease.

\section{Reg PROTEIN EXPRESSION PATTERNS AND PATHOPHYSIOLOGY}

\section{Pancreas}

Reg proteins were initially discovered in the regenerating rat islets following pancreatectomy (Terazono et al., 1988), and while the majority of published reports pertain to their expression in pancreatic cells, Reg proteins have also been implicated in pathological conditions of the digestive tract (Hervieu et al., 2006) as well as of other tissues, for instance, of the nervous (Duplan et al., 2001) and reproductive systems (Du and Yao, 2013).

There is very little information to date about the Reg expression during development. The REG1 mRNA exhibits a 20fold increase in the human acinar pancreas after 16 weeks of gestation (Mally et al., 1994). The expression of PAP (REG3) genes is also detected in fetal pancreas, stomach, jejunum, and colon (Bartoli et al., 1998). During mouse development, the presence of Reg1 mRNA is detected on E9 just before pancreatic organogenesis (Perfetti et al., 1996b) and on E13 in the fetal intestine (Ose et al., 2007). To our knowledge, there is no information available on the expression of Reg genes at earlier times of embryonic development, although we have reported the expression of Reg proteins in murine embryonic stem cells in culture (Jing et al., 2010). It should be noted however that transgenic mice featuring knockouts of various Reg genes [e.g., Reg1 (Unno et al., 2002), Reg3g (Vaishnava et al., 2011); Table 1] are born at normal Mendelian ratios and they show normal growth indicating that Reg proteins are dispensable for development.

Members of the Reg family are expressed primarily in normal pancreatic exocrine rather than endocrine cells (Michael et al., 1996; Baeza et al., 2001). Reg expression is age-dependent (Perfetti et al., 1996a; Martin et al., 2008; Wang et al., 2011) and increases during injury or inflammation. Indeed, various Reg proteins are linked to diabetes (Gurr et al., 2002; Martin et al., 2008; Astorri et al., 2010; Bacon et al., 2012; Cox et al., 2015; Yang et al., 2015), pancreatitis (Michael et al., 2000; Bluth et al., 2008; LaFonte et al., 2013) and pancreatic cancer (Grutzmann et al., 2003; Takehara et al., 2006; Legoffic et al., 2009; Park et al., 2011; Radon et al., 2015; Li et al., 2016b). 
TABLE 1 | Studies utilizing rodent models with Reg gene deletion of overexpression.

\begin{tabular}{|c|c|c|c|c|c|}
\hline $\begin{array}{l}\text { Reg family } \\
\text { type }\end{array}$ & Organ & Genotype & Treatment & Phenotype & References \\
\hline Murine Reg & Pancreas & $\begin{array}{l}\text { Reg }^{-/-}(\mathrm{KO}) \text { mouse, } \\
\text { insulin II promoter-Reg } \\
\text { (TG) mouse }\end{array}$ & $\begin{array}{l}\text { Goldthioglucose } \\
\text { (GTG)-induced islet cell } \\
\text { proliferation }\end{array}$ & $\begin{array}{l}\text { Islet size is independent of Reg genotype. KO } \\
\text { exhibits reduced thymidine incorporation; the } \\
\text { average size of hyperplastic islets treated with } \\
\text { GTG is decreased compared to control mice. } \\
\beta \text {-cell thymidine incorporation is increased in } \\
\text { TG; diabetes development is delayed in } \\
\text { NOD mice. }\end{array}$ & Unno et al., 2002 \\
\hline
\end{tabular}

\begin{tabular}{lll}
\hline $\begin{array}{l}\text { Murine } \\
\text { Reg1 }\end{array}$ & Pancreas & Encephalomyocarditis \\
& & (EMC) virus (D-variant) \\
& infection to induce $\beta$-cell \\
& damage and inflammation
\end{tabular}

Reg1 was overexpressed in ATLANTIS and exocrine acinar cells around islets of wild-type (WT) mice after EMC infection.

Thymidine incorporation in EMC virus-infected WT group is significantly higher than in EMC virus-infected $\mathrm{KO}$ mice and non-infected mice.

\begin{tabular}{|c|c|c|c|}
\hline $\begin{array}{l}\text { Murine } \\
\text { Reg1 }\end{array}$ & GI Tract & $\begin{array}{l}\text { Reg1-/-; } \\
\text { Reg1+/+ mouse }\end{array}$ & N/A \\
\hline $\begin{array}{l}\text { Murine } \\
\text { Reg2 }\end{array}$ & Pancreas & Reg2-/- mouse & $\begin{array}{l}\text { Streptozotocin (STZ) to } \\
\text { induce diabetes, caerulein } \\
\text { to induce acute } \\
\text { pancreatitis, high-fat diet }\end{array}$ \\
\hline
\end{tabular}

KO mice show significantly reduced intensity of proliferation marker in the crypt and decreased migration cell speed to the villus tip.

KO mice display no deficiency at young age Li et al., 2017
(3-4 months) but have impaired insulin
production and glucose tolerance later (13-14 months).

No difference in the symptom severity in either STZ-induced diabetes (8- to 10-week-old), or caerulein-induced pancreatitis (6- to 8-week-old). After high-fat diet for 19 weeks, islet mass expansion and serum insulin level were reduced in $\mathrm{KO}$ vs. WT. Blood glucose is significantly lower in KO mice vs. WT from 11 to 19 weeks.

\begin{tabular}{|c|c|c|}
\hline $\begin{array}{l}\text { Murine } \\
\text { Reg2 }\end{array}$ & Pancreas & $\begin{array}{l}\text { Elastase-1 promoter-Reg2 } \\
\text { (TG) mouse for acinar } \\
\text { cell-specific overexpression } \\
\text { of Reg2 }\end{array}$ \\
\hline
\end{tabular}

STZ-induced diabetes
Caerulein-induced acute
pancreatitis
TG shows no significant changes in Akt TG shows no significant changes in Akt
phosphorylation and levels of phosphoinositide 3-kinase, p85 and cyclin D1, normal islet growth and glucose homeostasis, and no protection against STZ-induced diabetes and caerulein-induced pancreatitis vs. WT.

Aida et al., 2018

Ose et al., 2007

\begin{tabular}{lll}
\hline Murine & Liver & $\begin{array}{l}\text { Reg2 }^{-/-} \text {mouse; } \\
\text { Reg2 }\end{array}$ \\
Reg2 & & Fas intoxication with \\
& & antibody J0-2; \\
& Partial hepatectomy
\end{tabular}

\begin{tabular}{|c|c|c|}
\hline $\begin{array}{l}\text { Human } \\
\text { REG3A }\end{array}$ & Liver & $\begin{array}{l}\text { REG3A } A^{+/+} \text {mouse } \\
\text { (hepatocyte expression) }\end{array}$ \\
\hline
\end{tabular}

Dextran sodium sulfate (DSS) solution, or 2,4,6-trinitrobenzene sulfonic acid (TNBS) to induce colitis; Paraquat to induce oxidative stress

\begin{tabular}{|c|c|c|c|}
\hline $\begin{array}{l}\text { Human } \\
\text { REG3A }\end{array}$ & Liver & $\begin{array}{l}\text { REG3A+/+ mouse } \\
\text { (hepatocyte expression) }\end{array}$ & $\begin{array}{l}\text { Partial hepatectomy; } \\
\text { TNF- } \alpha \text { and actinomycin D } \\
\text { (ActD) to induce apoptosis }\end{array}$ \\
\hline
\end{tabular}

\begin{tabular}{|c|c|c|c|}
\hline $\begin{array}{l}\text { Reg3b } \\
\text { Reg3g }\end{array}$ & Gl Tract & $\begin{array}{l}\text { Reg } 3 b^{-/-} \text {mouse } \\
\text { Reg } 3 g^{-/-} \text {mouse; } \\
\text { TG mouse with Reg3g } \\
\text { expression only in intestinal } \\
\text { epithelial and Paneth cells }\end{array}$ & $\begin{array}{l}\text { Ethanol-induced liver } \\
\text { disease }\end{array}$ \\
\hline
\end{tabular}

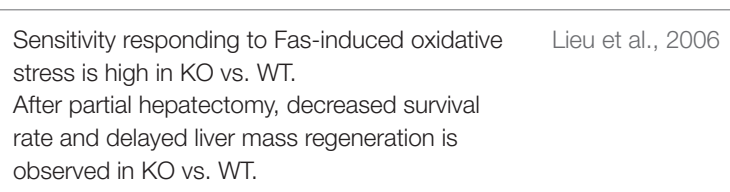

Sensitivity responding to Fas-induced oxidative Lieu et al., 2006
stress is high in KO vs. WT.

Liver regeneration is stimulated in TG as thymidine incorporation is significantly higher in

TG vs. WT after partial hepatectomy.

Primary TG hepatocytes show thymidine incorporation and higher viability vs. WT after treatment with $\mathrm{TNF}-\alpha$ and ActD.

Compared to ethanol-fed WT, ethanol-fed Reg3b KO mice develop more severe liver injuries progressing from steatosis to steatohepatitis, and display an increased number of mucosa-associated bacteria.
Li et al., 2010

Darnaud et al., 2018

Simon et al., 2003

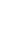


TABLE 1 | Continued

\begin{tabular}{|c|c|c|c|c|c|}
\hline $\begin{array}{l}\text { Reg family } \\
\text { type }\end{array}$ & Organ & Genotype & Treatment & Phenotype & References \\
\hline & & & & $\begin{array}{l}\text { Reg3g KO mice show severe progression of } \\
\text { ethanol-associated steatohepatitis, and display } \\
\text { a higher number of mucosa-associated bacteria } \\
\text { vs. WT but without a significant difference in the } \\
\text { microbiota before or after ethanol feeding. } \\
\text { Expression of the macrophage marker F } 4 / 80 \text {, } \\
\text { hepatic expression of Ccl2 and Cxc/5, and } \\
\text { TNF- } \alpha \text { are higher in ethanol-fed Reg3b and } \\
\text { Reg3g KO mice. } \\
\text { More Gram-negative bacteria in Reg3b KO than } \\
\text { in WT. Microbiota, intestinal permeability and } \\
\text { plasma levels of endotoxin are not significantly } \\
\text { different inReg3b KO. } \\
\text { Ethanol-fed Reg3g-TG mice have significantly } \\
\text { lower numbers of luminal bacteria, and less } \\
\text { bacterial translocation vs. ethanol-fed WT. }\end{array}$ & \\
\hline Reg3b & Pancreas & $\begin{array}{l}\text { Rat insulin I promoter } \\
\text { (RIP-I)-Reg3 } \beta \text { mouse }\end{array}$ & STZ-induced diabetes & $\begin{array}{l}\text { TG mice show partial protection against } \\
\text { delayed onset of hyperglycemia and weight } \\
\text { loss vs. WT after STZ treatment. }\end{array}$ & Xiong et al., 2011 \\
\hline Reg3g & Gl Tract & Reg3g ${ }^{-/-}$mouse & $\begin{array}{l}\text { Bone marrow } \\
\text { transplantation (BMT) }\end{array}$ & $\begin{array}{l}\text { KO mice exhibit severe graft-versus-host } \\
\text { disease (GVHD) and higher mortality after BMT } \\
\text { compared to WT animals. } \\
\text { Fecal microbiota composition does not differ } \\
\text { between KO and WT either before BMT or } \\
\text { during GVHD. }\end{array}$ & Zhao et al., 2018 \\
\hline Reg3g & Gl Tract & Reg3g-/- mouse & $\mathrm{N} / \mathrm{A}$ & $\begin{array}{l}\text { KO shows increased number of } \\
\text { mucosal-associated Gram-positive bacteria, no } \\
\text { difference in Gram-negative bacteria, and an } \\
\text { increased activation of adaptive immunity } \\
\text { vs. WT. }\end{array}$ & Vaishnava et al., 2011 \\
\hline
\end{tabular}

WT, Wild-type; KO, Knock-out; TG, Transgenic.

\section{Diabetes}

Increased circulating serum levels of REG1A are manifested across different types of diabetes including type 1 (T1D) (Astorri et al., 2010; Bacon et al., 2012), maturity onset diabetes of the young (MODY) (Astorri et al., 2010; Bacon et al., 2012) and type 2 (T2D) (Yang et al., 2015) indicative of $\beta$-cell apoptosis. T2D patients show upregulated Reg both at initial diagnosis and after the emergence of long-term complications. Reg levels in T2D and MODY, but not in T1D patients, correlate with the time since the onset of the disease (Wang et al., 2011; Bacon et al., 2012). T1D patients with increased REG1A exhibit significantly greater levels of corresponding autoantibodies than non-diabetic and T2D subjects (Astorri et al., 2010). After gastric bypass surgery, which allows to achieve glycemic control and reduce insulin resistance in T2D patients, upregulation of REG1A and REG3G may contribute to T2D remission (Sala et al., 2017).

A distinct type of acinar-like cell clusters touching Langerhans islets with thin interstitial surrounding (ATLANTIS) was reported in both healthy and diabetic pancreases (Aida et al., 2014) (Table 1). Those cell clusters were found to secret vesicles containing REG1A to neighboring islet cells in the non-diabetic human pancreas. In contrast, REG1A was overexpressed in ATLANTIS under diabetes
(Aida et al., 2014). Furthermore, REG1 was overexpressed in ATLANTIS of $R e g 1^{-/-}$mice vs. their wildtype counterparts after encephalomyocarditis (EMC) virus infection characterized by $\beta$-cell damage and inflammation (Aida et al., 2018). This indicates that REG proteins are crucial in beta cell regeneration in this context.

In mice, knocking down Reg reduces the average islet size and thymidine incorporation (Unno et al., 2002). In contrast, transgenic non-obese diabetic (NOD) mice expressing Reg from the rat insulin II promoter (Ins-Reg) show increased $\beta$-cell regeneration and diminished hyperglycemia. Such findings and the reported mitogenic effects on $\beta$-cells (Michael et al., 1996; Borelli et al., 2005; Cox et al., 2015) support the notion that Reg proteins may serve as biomarkers (Astorri et al., 2010) and treatment targets for diabetes (Watanabe et al., 1994; Gross et al., 1998; Gurr et al., 2002; Li et al., 2010; Hou et al., 2011). For instance, administration of Reg protein induces $\beta$-cell mass expansion in female NOD mice (Gross et al., 1998) and rats with surgical diabetes (Watanabe et al., 1994). The overexpression of Reg1 and Reg3 $\beta$, but not Reg2, ameliorates streptozotocin (STZ)-induced diabetes in mice and accelerates recovery ( $\mathrm{Li}$ et al., 2010; Hou et al., 2011; Xiong et al., 2011). Reg2-/mice display no deficiency at young age (3-4 months) but 
have impaired insulin production and glucose tolerance at a later age (13-14 months) (Li et al., 2017). Reg2 expression appears to contribute to obesity-induced islet compensation as Reg $2^{-/-}$mice show only $25 \%$ of the islet expansion exhibited by wild-type animals on high-fat diet (Table 1). The findings suggest that Reg2 expression is needed for islet expansion in aged mice or those on high-fat diet. It is worth noting that according to an earlier report (Wang et al., 2011) Reg2 peaks at 1 month, becomes undetectable after 3 months and is induced by obesity (Qiu et al., 2005) but its mechanism(s) of action remains unclear.

\section{Pancreatitis}

The expression of Reg1 and Reg3 in humans, mice and rats is linked to pancreatitis (Satomura et al., 1993; Michael et al., 2000; Bluth et al., 2008; LaFonte et al., 2013) as constituents of calciferous plugs manifested during the disease. In rodent models, Reg expression increases in chemical agent-induced pancreatitis or after pancreatitis surgery (Bluth et al., 2006, 2008). In addition, a significant elevation in Reg3 - but not Reg1 - is reported in the early phase of rat pancreatitis (Dieckgraefe et al., 2002). Pancreatic duct ligation lowers both the acinar cell mass and Reg1 production (Bluth et al., 2008). Other types of Regs have been probed in caerulein- or sodium taurocholate-induced pancreatitis. Reg2 overexpression appears to have little overall effect on pancreatitis ( $\mathrm{Li}$ et al., 2010), whereas blocking of Reg1 and PAP-II with antibodies worsens the condition (Viterbo et al., 2009). These results are aligned with the general notion of Reg upregulation during inflammation.

\section{Pancreatic Cancer}

Reg proteins have also been investigated in the context of pancreatic cancer such as PDAC (Kleeff et al., 2016). Proliferating tumor cells in early stage PDAC express REG1A, REG1B, REG3A, and REG4 and throughout PDAC development (Takehara et al., 2006; Li et al., 2016b). The proteins are also elevated in the serum and urine of PDAC patients. Therefore, several groups suggested that Reg proteins may serve as biomarkers for early detection of pancreatic cancer (Grutzmann et al., 2003; Takehara et al., 2006; Legoffic et al., 2009; Park et al., 2011; Radon et al., 2015). Interestingly, higher levels of REG1A and REG1B are correlative with higher survival rates (Li et al., 2016b).

REG1A, REG3A, and REG3G expression is not observed in normal acini and ducts but is detectable in tumor-adjacent acinar areas (Zhou et al., 2010; Li et al., 2016b). Similarly, Reg $3 b$ is elevated in healthy acinar tissue near PDAC tumors and may interfere with the uptake of extracellular vesicles. Reg3b deficiency can also induce an alternative immune microenvironment in $\mathrm{PDAC}$ by reducing the $\mathrm{M} 2 / \mathrm{M} 1$ ratio of tumor-associated macrophages and upregulating $\mathrm{CD} 3^{+}$cell infiltration through the activation of the STAT3 signaling pathway (see also section Signaling Pathways) (Gironella et al., 2013). However, the net effect of Reg $3 b$ on the pathology remains unclear. Limiting the uptake of vesicles may reduce the tumor volume near acinar cells and conversely increase tumorproduced extracellular vesicles throughout the bloodstream thereby enabling metastasis (Bonjoch et al., 2017). Reg3b and
Reg3g reportedly promote the transition from pancreatitis to pancreatic cancer participation in the JAK2-STAT3 signaling axis (Loncle et al., 2015).

Introduction of recombinant REG4 enhances growth of a PDAC cell line in a dose-dependent manner. The use of a monoclonal antibody against REG4 counteracts the proliferation effect by inhibiting the REG4 autocrine/paracrine pathway and the subsequent phosphorylation of Akt (Takehara et al., 2006).

\section{Extra-Pancreatic Tissues}

Reg proteins are implicated in cancer, inflammation or injury of tissues beyond the pancreas, including in the gastrointestinal (GI) tract, brain, liver and skin.

\section{GI Tract}

In the GI tract, Reg proteins are expressed in the gastric mucosa, colon, and small intestine and have been linked to cell proliferation.

REG1A and REG1B are upregulated in human colonic or gastric mucosa with inflammatory bowel disease (IBD) (van Beelen Granlund et al., 2013) and ulcerative colitis (UC) (Tsuchida et al., 2017). Immunostaining of human colonic samples showed that REG1A correlated with TP53 (p53) overexpression in the development of UC-associated neoplasia (Tanaka et al., 2011) while a considerable number of p53overexpressing high-grade dysplasias and invasive carcinomas were negative for REG1A. Interestingly, others have reported no significant relationship between p53 and REG1A in gastric cancers (Watanabe et al., 1990; Fukui et al., 2004; Sekikawa et al., 2005). Interleukins (ILs) in UC regulate Reg protein expression, particularly of REG1A that is stimulated by IL-22 and IL-6 (Sekikawa et al., 2010; Tsuchida et al., 2017), and of REG1B promoted by IL-22 (Tsuchida et al., 2017). It should be noted that IL-22 stimulation of REG1A is based on the presence of IL-activatable elements of the REG1A promoter and may be mediated through STAT3 tyrosine phosphorylation as in colon cancer cells in vitro (Sekikawa et al., 2010).

In celiac disease, serum levels of REG1A are over two-fold greater than normal but are reduced with the adoption of a gluten-free diet (Planas et al., 2011). Interestingly, REG1A appears to protect from bowel damage due to the use of non-steroidal anti-inflammatory drugs (NSAIDs), such as acetaminophen or ibuprofen. Increases in REG1A and REG1B are observed in acute amoebic colitis, a parasitic infection. In mice, Reg1 expression confers protection after exposure to E. histolytica (Peterson et al., 2011). Taken together, these findings support the surge in Reg proteins following GI tract damage caused by a multitude of factors.

Similar to other tissues, the link between Reg protein action and proliferation is suggested in the GI tract. Reg1 in the murine small intestine reportedly regulates growth that is essential for the generation and maintenance of the crypt-villus growth axis of the small intestinal mucosa, as $\mathrm{Reg}^{-/-}$mice shows significantly decelerated growth and migration of the intestinal epithelial cells to the villus tip (Ose et al., 2007). The pro-proliferative effect of Reg proteins may alleviate damages due to autoimmunity but could increase the risk of colon or gastric tumorigenesis. 
REG1A is associated with severe infiltration, poor prognosis and lymphatic invasion, but not with tumor size, tumor stage or p53 overexpression in gastric cancer as already mentioned (Watanabe et al., 1990; Fukui et al., 2004; Sekikawa et al., 2005). Increased REG1A is believed to promote cell growth or protect from apoptosis within tumors (Kadowaki et al., 2002; Sekikawa et al., 2005) but reports are conflicting. Knocking down REG1A (and REG3A) in gastric cancer cells leads to greater proliferation and infiltration whereas overexpression coincides with enhanced apoptosis (Qiu et al., 2017, 2018).

REG3A is expressed in the small intestine and is upregulated in IBD, possibly to attenuate inflammation and restore gut microbiota (van Beelen Granlund et al., 2013; Darnaud et al., 2018). REG3A appears to play a dual role in the intestine as a bactericidal agent and reducing apoptosis of epithelial cells. Upon digestion of the N-terminal pro-segment of REG3A by trypsin in the gut lumen, the protein binds to the surface peptidoglycans of Gram-positive bacteria, assembling into hexamers forming pores thereby compromising the membrane and eventually killing the bacterial targets (Mukherjee et al., 2014). The presence of the prosegment potentially prevents unintended damage of the epithelial cells producing REG3A. Reg3b is expressed in murine intestinal epithelial cells and inhibits intestinal translocation of the Gramnegative Salmonella enteritidis bacteria upon oral infection, but not of the Gram-positive Listeria monocytogenes (van Ampting et al., 2012). The expression of REG3G was predominantly observed in epithelial cells of the airway and intestine with a gradual increase during mouse development (Matsumoto et al., 2012). The antibacterial action of Reg3g mediates the spatial segregation of Gram-positive microbiota and the small intestinal epithelial surface (Vaishnava et al., 2011). Reg3 $g^{-/-}$mice display a higher number of mucosa-associated bacteria vs. their wildtype littermates but without a significant difference in the colon microbiota where Reg3g expression is low relative to that in the small intestine. However, overexpression of Reg3g in murine intestinal epithelial cells restricts bacterial colonization of mucosal surfaces and prevents bacterial translocation. In the same context, the presence of REG3G correlates with reduced steatosis and liver disease due to alcohol administration (Wang L. et al., 2016). Besides its antibacterial activity, REG3A serves as a survival signal to prevent apoptosis of crypt cells with graft-versus-host disease (GVHD) in allogeneic bone marrow transplantation (Zhao et al., 2018). Elevated serum REG3A is a strong indicator of GVHD in the GI tract with poor outcomes (Ferrara et al., 2011). Reg3 $g^{-/-}$mice exhibited severe GVHD and higher mortality after bone marrow transplantation compared to wild-type littermates. Administration of IL-22, which upregulates the expression of Reg3g (Zheng et al., 2008), prevented GHVD, increased Reg3g production in the ileum and decreased serum Reg3g levels but had no effect on $\operatorname{Reg} 3 g^{-/-}$mice. Incubation of TNF- $\alpha$-treated HT-29 colorectal cells with recombinant REG3A reduced caspase cleavage and increased viability. Taken together, REG3A acts as a bactericidal and pro-survival signal in the intestinal milieu.

Another Reg member, Reg4, is expressed in UC tissues in correlative levels with basic FGF (bFGF) and hepatocyte growth factor (HGF) mRNA (Nanakin et al., 2007). REG4 was actually isolated from an inflammatory bowel disease cDNA library (Hartupee et al., 2001) and it is overexpressed in colon mucosa with Crohn's disease (CD) (Nanakin et al., 2007; Tsuchida et al., 2017). Moreover, Reg4 has been identified as a marker of deep crypt secretory cells in $\mathrm{Lgr}^{+} / \mathrm{CD} 24^{+}$sorted cells, and Reg $4^{+}$cells promote organoid formation of single $\operatorname{Lgr} 5^{+}$colon stem cells (Sasaki et al., 2016). REG4 is thought to be an early stage serum biomarker of gastric cancer metastasis (Tao et al., 2011) and resistance to apoptosis after treatment with 5-fluorouracil (5-FU) used for chemotherapy (Mitani et al., 2007). REG4 expression is directly regulated by the CDX2 protein, an important transcriptional factor for development of intestinal epithelial cells, by binding to the 5 -flanking region of REG4 (Naito et al., 2012). In diffuse-type gastric carcinoma cells, TGF- $\beta$ signaling inhibits REG4 expression in the cancerinitiating cells (Katsuno et al., 2012). Colorectal cancer patients with high tumor content of REG4 exhibit a poorer overall survival rate and disease-free survival rates compared to patients with tumors devoid of REG4 (Zhu et al., 2015). While the reason for this remains to be elucidated, REG4 appears to accelerate the transition through cell cycle promoting mitosis by upregulating the genes for cyclins D1 (CCND1) and D3 (CCND3), and for cyclin-dependent kinases CDK4 and CDK6 (Bishnupuri et al., 2014). In fact, REG4 knockdown induces apoptosis and inhibits the proliferation of colon cancer cells (Vanderlaag et al., 2012). This effect may be mediated by the transcription factor GATA6 regulating proliferation and development in the GI tract (Kawasaki et al., 2015). MicroRNA-363, which is reduced in colon tumors, suppresses GATA6 leading to REG4 downregulation (Kawasaki et al., 2015).

\section{Nervous System}

Reg proteins are also involved in the pathophysiology of the nervous system. Reg1, Reg2/PAP1, PAPII, PAPIII and Reg4, are upregulated after injury of the motor neurons in rats (Namikawa et al., 2005) and PAPIII expression, specifically, is correlated with regeneration time (Namikawa et al., 2006). Reg1 is reported to stimulate neurite outgrowth through the EXTL-3 receptor in both mice and rats (Acquatella-Tran Van $\mathrm{Ba}$ et al., 2012). In animal models of tauopathy, Reg1 also regulates tau protein phosphorylation via the AKT/GSK3- $\beta$ pathway only if tau is in a pre-phosphorylated state (Moussaed et al., 2018). PAP-1 and PAP-III proteins may protect against damaging factors in traumatic brain injury (TBI) and seizure, as PAP-1 is overexpressed in central neurons in human TBI patients, and PAP-1 and PAP-III are expressed in the hippocampal and parahippocampal areas after kainic acidinduced seizure in rat models (März-Weiss et al., 2011). HIP/PAP (REG3A) rescued neuronal death and glial activation after neuronal damaging factors in vivo, further suggesting that this Reg protein has neuroprotective/neuroregenerative effects (Haldipur et al., 2014). Rat PAP-III protein undergoes proteolytic N-terminal cleavage by trypsin-like protease(s) in injured sciatic nerves after axotomy, and mediates neurite elongation (Konishi et al., 2013). Besides brain injuries, Reg family proteins such as Reg1 and Reg3 are present in the plaques and neurofibrillary tangles of patients with Alzheimer 
disease. Greater levels of these Reg proteins are found in the cerebrospinal fluid of Alzheimer patients, compared to those of normal subjects and even of patients with multiple sclerosis (Duplan et al., 2001).

Rat Reg2 may prevent demyelization and promote regrowth of myelin after injury (Jiang et al., 2016). Reg2 is expressed in primary rat Schwann cells in vitro and in vivo in both sensory and motor neurons during development. This is stimulated by peripheral nerve axotomy in adult rats. Inhibition of Reg2 signaling activity by antisera hinders regeneration of Reg $2^{+}$axons (Livesey et al., 1997). Although the addition of recombinant Reg2 has a weak proliferation effect in Schwann cells in vitro, it is significantly mitogenic in a dose-dependent manner in the presence of forskolin, an activator of adenylyl cyclase (Livesey et al., 1997). During mouse development, transient expression of Reg $3 b$ is observed in specific subsets of motor neurons and primary sensory neurons during embryonic and perinatal stages (Matsumoto et al., 2012). Reg3b (the homolog of Reg2 in rats) deletion delays myelination in subsets of hypoglossal motor neurons in mice but does not induce motor neuron cell death (Tebar et al., 2008).

\section{Liver}

REG3A was initially identified as hepatocarcinoma-intestinepancreas/pancreatic associated protein (HIP/PAP) due its elevated gene expression in human hepatocellular carcinoma (HCC) in comparison to normal liver tissues (Lasserre et al., 1994; Cervello et al., 2002). Reg3a is absent in normal adult hepatocytes, most likely due to a silencer region in its promoter that is inactive in hepatoma cells (Dusetti et al., 1996b). Reg3a is also not detected in human fetal liver or during development of post-implanted mouse embryos (Lasserre et al., 1999). The upregulation of REG3A correlates with early stage HCC and $\beta$-catenin mutation, and it is reported to be a downstream target of $\beta$-catenin mutation in the Wnt pathway in vitro (Yuan et al., 2005; Cavard et al., 2006). We also found that Reg1 expression is modulated by canonical Wnt signaling in murine embryonic stem cells (Jing et al., 2010). Taken together, these studies suggest that Reg expression is associated with hepatic cancer cell proliferation or differentiation during hepatocellular carcinogenesis.

Besides its role in HCC, REG3A acts an extracellular matrix (ECM)-targeted scavenger of reactive oxygen species (ROS) in a dose dependent manner (Moniaux et al., 2011) preventing ROSinduced-mitochondrial damage due to acetaminophen overdose (Lieu et al., 2005).

Another Reg member, REG1, is upregulated in newly formed bile ductular structures in a rat liver regeneration model (Wang et al., 2009). In Reg2 $2^{-/-}$mice, liver regeneration is markedly delayed, sensitivity responding to Fas-induced oxidative stress is high, and the IL-6/STAT-3 pathway is active (Lieu et al., 2006).

Overall, while Reg protein activity increases during liver regeneration and disease, the physiological significance of this pattern warrants further investigation.

\section{Other Cancer Types and Maladies}

The presence of REG1A is reported in extrapancreatic cancer types including non-small cell lung cancer (Minamiya et al., 2008), breast cancer (Sasaki et al., 2008), bladder cancer (Geng et al., 2017) and colorectal sessile serrated adenoma (Okamoto et al., 2013). Despite the negative prognosis associated with REG1A (Minamiya et al., 2008; Sasaki et al., 2008; Hara et al., 2015; Geng et al., 2017), higher REG1A in thoracic esophageal squamous cell carcinoma is indicative of increased sensitivity to chemotherapy treatment (Sato et al., 2013) and lower levels of lymphatic permeation and vascular invasion (Aboshanif et al., 2016).

REG1A is also upregulated in the minor salivary glands of patients with Sjörgen's Syndrome (SS), an autoimmune condition characterized by dryness of the eyes and mouth. The protein is believed to play a role in the regeneration of ductal cells in these tissues (Kimura et al., 2009).

Reg proteins are also implicated in wound healing. REG3A enhances keratinocyte proliferation and differentiation after skin injury by stimulation via IL-17 (Lai et al., 2012). Human REG3A or murine Reg3g are overexpressed in epidermal hyperproliferative keratinocytes in psoriasis (Lai et al., 2012).

Several Reg family mRNAs are also detected in the rat periosteum, which is a membrane tissue enveloping the outer surface of bones (Tohma et al., 2017). Reg1 gene expression is significantly augmented in the periosteum during the healing period after a significant bone fracture (Tohma et al., 2017). In periosteum-derived mesenchymal stem cells, IL-6 induces Reg expression and proliferation (Tohma et al., 2017). Interestingly, Reg expression is absent in the bone, bone marrow or muscles.

\section{SIGNALING PATHWAYS AND Reg PROTEINS}

A widely accepted signaling mechanism for the action of Reg proteins is still lacking. Our review encompasses human Reg members and their rodent analogs while studies on Reg3d [INGAP - islet neogenesis-associated protein (Rafaeloff et al., 1997)] are not summarized due to space limitations.

\section{Putative Reg Receptors}

The difficulty of establishing the molecular pathways associated with Reg stems in large part from the fact that receptors of Reg remain elusive. Using a rat islet cDNA expression library, Kobayashi et al. (2000) identified a putative receptor of rat Reg1. This receptor corresponded to the human EXTL3, a member of the exostosis family comprising glycosyltransferases contributing to heparan sulfate synthesis. Overexpression of EXTL3 increases the effect of REG1A on neurite outgrowth (Acquatella-Tran Van Ba et al., 2012) and the two proteins colocalize by immunostaining analysis of rat PC12 cells and primary hippocampal neurons. However, the Reg1/EXTL3 interaction has not been shown conclusively (e.g., by coimmunoprecipitation). In fact, findings from the same group that identified EXTL3 as a Reg receptor indicated that 
this is unlikely to act upstream of kinases believed to be targeted by Reg (Kadowaki et al., 2002). Moreover, in a yeast two-hybrid analysis focusing on binding partners of rat Reg1, none of the identified clones exhibited homology with the EXTL3 gene (Mueller et al., 2008) (see below). Importantly, there is no known signaling role for EXLT3. EXTL3 possibly induces NF- $\kappa$ B activity with TNF- $\alpha$ stimulation (Mizuno et al., 2001), and Reg1 expression is related to inflammatory responses but there is no established link between these observations.

Interactions of other Reg proteins with receptors are also debatable or unknown. The binding of REG3A to the epidermal growth factor receptor (EGFR) was suggested given that the two moieties colocalize upon immunostaining of SW1990 pancreatic adenocarcinoma cells and EGFR/REG3A complexes are detected by co-immunoprecipitation (Liu et al., 2015). Cells incubated with REG3A have lower expression of cyclin D1 when treated with the EGFR inhibitor Erlotinib. Additionally, blocking of EXTL3 did not affect the REG3Ainduced cell proliferation suggesting that EXTL3 is not part of the REG3A cascade. The gp130 transmembrane protein of the JAK-STAT cascade is suggested as a Reg3 $\beta$ receptor (see Signaling Pathways) (Loncle et al., 2015). REG4 purportedly interacts with the G-coupled receptor 37 (GPR37) in gastric cancer cells to promote metastasis (Wang $\mathrm{H}$. et al., 2016). These findings warrant extensive studies to conclusively demonstrate the reported interactions of Reg with the stated receptors and address whether these are cell-type specific or generally applicable.

\section{Signaling Pathways}

Our knowledge of cascades relaying Reg signals remains incomplete and surveys of the relevant literature lead at times to conflicting conclusions. Induction of $\beta$-cell regeneration by Reg1 is reportedly mediated by the phosphoinositide-3kinase (PI3K) acting on the transcriptional factor ATF2. This results in upregulation of cyclin D1, which is suppressed when RINm5F $\beta$-cells are treated with the PI3K inhibitors LY294002 and wortmannin. Moreover, murine $\mathrm{Reg}^{-/-}$islets display decreased phosphorylated (active) ATF2 and retinoblastoma $(\mathrm{Rb})$ proteins. Interestingly, inhibition of the MAPK kinases MEK1 and MEK2 does not change significantly the cyclin D1 promoter activity in $\beta$-cells. In another study (Kadowaki et al., 2002) however, Reg overexpression is shown to promote proliferation of gastric cancer cells via activation of the MEK1/2-targeted ERK1/2 but not p38 and JNK. Similarly, murine primary acinar cells treated with Reg $3 \alpha$ exhibit higher levels of phosphorylated ERK1/2 (Li et al., 2016b). Whether these discrepancies about the role of ERK1/2 as mediator of Reg signals point to contextual differences is an open question. Reg1 binds to MKP-1 for regulation of cyclin D in rat ductal cells (Mueller et al., 2008). Here though, exposure to Reg1 increased the phosphorylation of not only ERK1/2 but also JNK and p38. Moreover, the reversal of the suppression of JNK phosphorylation by streptozotocin in MIN6 cells has been correlated with murine Reg2 (Liu et al., 2010).
The gp130-JAK2-STAT3 cascade is also reported to mediate the effects of Reg3b (Loncle et al., 2015). Systemic administration of recombinant Reg3b protein rescues PanIN formation in Reg3b-deficient mice and the same Reg is upregulated in cultured AR-42J (rat) acinar cells after treatment with IL17A. Neutralization with antibodies for Reg3b or IL17A inhibits PanIN development in Pdx1-Cre; Kras ${ }^{G 12 D}$; Reg3b $\mathrm{b}^{+/+}$mice. Reg3b signals through the gp130-JAK2-STAT3 axis promoting cell growth and resistance to apoptosis based on the decline in the number of $\mathrm{Reg} \mathrm{b}^{+}$cells from the peritumoral region to PDAC lesions exhibiting poorly differentiated cells [although the pattern of Reg3b in this report was debated ( $\mathrm{Li}$ et al., 2016a; Loncle et al., 2016)]. Along the same lines, REG3A was linked to the activation of the JAK2-STAT3 pathway in pancreatic cancer cell lines (Liu et al., 2015) and of the MAPK in acinar cells (Ferres-Maso et al., 2009). It is suggested that REG3A synergistically with interleukins (e.g., IL-6) promotes proliferation of pancreatic cancer cells via a REG3A-JAK2STAT3 positive feedback loop. Further studies are warranted to shine light on the signaling mediated by REG3A and Reg3b signaling.

Murine Reg3a overexpression in MIN6 insulinoma cells leads to increased (1.8-fold) Akt phosphorylation and cyclin D1/cdk4 levels concomitant with enhanced proliferation rate $(\sim 2$-fold vs. cells transfected with empty vector) (Cui et al., 2009).

REG4 also phosphorylates AKT in addition to EGFR in gastric cancer cells (Kuniyasu et al., 2009) resulting in the increased expression of anti-apoptotic BCL-2, BCL-XL and BIRC5. The repertoire of phosphorylation targets for REG4 includes Erk, Hsp27 and GSK3 $\beta$ in colon and prostate cancer cell lines (Vanderlaag et al., 2012). In contrast to findings for other Reg members, there were no detectable changes in p38 MAPK and JNK upon REG4 stimulation or knockdown. Multiple receptor tyrosine kinases (RTKs) are impacted by REG4 although the nature of this effect depends on the cell type. Phosphorylation of the insulin and insulin-like growth factor receptors is stimulated in HCT116 cells but suppressed in PC3 and KM12 cells whereas EGFR phosphorylation is also decreased in PC3 cells but is unaffected in the other two lines. Knockdown of REG4 resulted in the induction of p21 and p27, reduction of S-phase cells and the lowering of the anti-apoptotic BCL-2. Given that other growth factors realize their effects through RTKs, a crosstalk or feedback is plausible between Reg4 and such ligands.

The phosphorylation of Akt and GSK-3 $\beta$ by REG4 is also shown for signaling through the $\beta$-catenin and TCF4 (Bishnupuri et al., 2014). Consequently, the Reg4-mediated activation of TCF4 results in the upregulation of cyclin D1 and D3 and their partners CDK4 and CDK6 enhancing the proliferation of human colorectal cancer cells. Phosphorylation of Akt by REG4 through the EGFR and activation of ERK1/2 and CREB reportedly trigger the polarization of macrophages to M2 phenotype (Ma et al., 2016). Taken together, these findings suggest that Reg4 acts on RTKs, such as the EGFR, causing the phosphorylation of Akt with downstream effects on genes controlling cell proliferation and apoptosis, particularly in GI cancer cells. The aforementioned studies 
give an incomplete picture of the role of Reg4 in normal cells but reveal candidate moieties for further investigation of Reg4 signaling.

\section{CHALLENGES}

An obvious hindrance in the field of Reg protein biology has been the use of multiple names to refer to specific Reg members or forms (whole vs. cleaved polypeptide sequence). This has imposed significant challenges on comparative analyses of findings from published studies thereby making arduous the advancement of knowledge about these proteins. Therefore, the use of standard Reg gene/protein nomenclature among different research groups is essential.

Additionally, the cross-reference and conceivably interchangeable use of human and rodent Reg homologs within the same work oftentimes exacerbates difficulties in interpreting results and contrasting them with those from other studies. For example, the human REG3A has been suggested as an ortholog of mouse Reg3b (e.g., ref., Loncle et al., 2016) based on amino acid sequence homology (69\%; Figure 1). REG3A is also $67 \%$ homologous to murine Reg3g (Reg3gamma) and this similarity has been pointed out in other studies (e.g., refs. Vaishnava et al., 2011; Mukherjee et al., 2014). It should be noted that Reg3b and Reg3g share $70 \%$ of their amino acids but are not identical proteins. Whether Reg3b and Reg3g serve the same purpose possibly compensating each other in mice is presently unclear. More importantly, caution should be exercised when extrapolating findings for a particular Reg member from one species to a member(s) with partial sequence homology in a different organism.

The generation of wild-type and modified Reg proteins in a variety of hosts including E. coli (Lee et al., 2003; Cash et al., 2006), yeast (Li et al., 2003), mammalian (HEK293 or CHO) cells (Namikawa et al., 2006) and even transgenic mice (Christa et al., 2000) has aided significantly the research on various aspects of Reg protein biology. For instance, recombinant rat PAP2 protein produced in E. coli with either a GST or 6xHis tag (Viterbo et al., 2010) is detected by western blotting at the expected size, mediates bacterial aggregation and causes the upregulation of interleukins (IL- $1 \alpha,-1 \beta$ and -6 ) and TNF- $\alpha$ genes in rat NR8383 macrophages. It should be noted that various Reg members (e.g., lithostathine) feature glycosylation moieties, which may contribute to the protein function and therefore bacterial (lacking glycosylation) and yeast (typically mannose-rich glycosylation) systems may not be ideal for the production of recombinant Reg products with physiological activity. In most cases, the downstream purification rather than the expression of recombinant Reg in culture presents challenges, given the issues surrounding the solubility, aggregation and autocleavage of these proteins.

Reports involving the production or use of recombinant Reg proteins also make apparent the lack of standardized assays for testing the activity of these proteins. This stems mainly from our incomplete picture of the exact cellular responses triggered by Reg proteins and the underpinning mechanisms. The induction of IL genes in macrophages and bacterial aggregation mentioned have been viewed as processes resulting from Reg exposure as mentioned above. Given the role of Reg as pro-proliferative agent, the growth of cells in culture has been used as a readout of recombinant Reg bioactivity. However, these cells are typically transformed and thus highly proliferative making challenging the accurate assessment of proliferation changes elicited by a particular Reg. Moreover, the presence of serum in the maintenance medium may confound any effects solely due to Reg. The anti-apoptotic role of Reg is also exploited in activity assays as a reduction in the loss of cell viability and caspase 3/7 activity in response to a cytotoxic agent (Loncle et al., 2015). The phosphorylation of ATF2 and activation of cyclin D1 promoter activity as downstream effectors of Reg have also been probed in a limited number of studies (Takasawa et al., 2006). The quantification of outgrowth of primary neurons or respective lines (e.g., N2a, Acquatella-Tran Van Ba et al., 2012) in culture after exposure to recombinant Reg has also been employed in checking the activity of laboratory-produced and commercially available recombinant Reg proteins. The mechanism of Reg-induced neurite extension is still unsettled. The assay outcome is very sensitive to the culture conditions including cell seeding density, type of matrix used for cell attachment, and regimen for changing media. To this end, the development of standardized assays with robust readouts and amenable to validation for determining Reg bioactivity will be essential for further progress in this field. Such assays will reduce the variability in the activity of different batches of recombinant Reg proteins prepared commercially or by individual laboratories.

Lastly, the potential regulation of Reg gene expression by microRNAs (miRNAs) has been largely unexplored. Recently, the murine reg1, which displays a $3^{\prime}$-UTR region that matches the seed of miRNA-7 (miR-7), was shown to be a direct target of this miRNA (Downing et al., 2019). Interestingly enough, miR-7 expression is higher in the islets than in exocrine cells (200:1) (Bravo-Egana et al., 2008; Correa-Medina et al., 2009) whereas Reg1 is abundant in acinar cells but not in normal islets. Because miR7 has roles in $\beta$-cell proliferation and function, avenues are opened for exploring possible connections with the regulation of reg1 expression and potentially shining more light on Reg function. The same study (Downing et al., 2019), however, demonstrated that unlike reg1, the human REG1A and REG1B are not targeted directly by miR-7. This exemplifies further that regulation of Reg expression may not be universal but species-dependent. To this date, there have been no reports of miRNA regulation of the expression of human Reg genes.

In summary, Reg proteins appear to assume multiple roles as pro-proliferative, anti-apoptotic and bactericidal agents. This repertoire warrants further research to expand our knowledge on the regulation and functional attributes of each Reg member, 
and potential synergies among distinct Reg proteins. Expediting research progress in this area will require addressing challenges including the ones discussed above. Given that several reports have linked Reg moieties to a gamut of maladies, particularly of the pancreas and GI tract, the idea is appealing that these proteins may serve as therapeutic targets and biomarkers.

\section{AUTHOR CONTRIBUTIONS}

ZC, SD, and ET researched the relevant literature, wrote the manuscript and approved its submitted form.

\section{REFERENCES}

Aboshanif, M., Kawasaki, Y., Omori, Y., Suzuki, S., Honda, K., Motoyama, S., et al. (2016). Prognostic role of regenerating gene-I in patients with stage-IV head and neck squamous cell carcinoma. Diagn. Pathol. 11:79. doi: 10.1186/s13000016-0526-y

Acquatella-Tran Van Ba, I., Marchal, S., Francois, F., Silhol, M., Lleres, C., Michel, B., et al. (2012). Regenerating islet-derived lalpha (Reg-1alpha) protein is new neuronal secreted factor that stimulates neurite outgrowth via exostosin Tumor-like 3 (EXTL3) receptor. J. Biol. Chem. 287, 4726-4739. doi: 10.1074/ jbc.M111.260349

Aida, K., Kobayashi, T., Takeshita, A., Jimbo, E., Nishida, Y., Yagihashi, S., et al. (2018). Crucial role of Reg I from acinar-like cell cluster touching with islets (ATLANTIS) on mitogenesis of beta cells in EMC virus-induced diabetic mice. Biochem. Biophys. Res. Commun. 503, 963-969. doi: 10.1016/j.bbrc.2018.06.103

Aida, K., Saitoh, S., Nishida, Y., Yokota, S., Ohno, S., and Mao, X. (2014). Distinct cell clusters touching islet cells induce islet cell replication in association with over-expression of Regenerating Gene (REG) protein in fulminant type 1 diabetes. PLoS One 9:e95110. doi: 10.1371/journal.pone.0095110

Astorri, E., Guglielmi, C., Bombardieri, M., Alessandri, C., Buzzetti, R., and Maggi, D. (2010). Circulating Reglalpha proteins and autoantibodies to Reg1alpha proteins as biomarkers of beta-cell regeneration and damage in type 1 diabetes. Horm. Metab. Res. 42, 955-960. doi: 10.1055/s-0030-1267206

Bacon, S., Kyithar, M. P., Schmid, J., Rizvi, S. R., Bonner, C., and Graf, R. (2012). Serum levels of pancreatic stone protein (PSP)/reg1A as an indicator of betacell apoptosis suggest an increased apoptosis rate in hepatocyte nuclear factor 1 alpha (HNF1A-MODY) carriers from the third decade of life onward. BMC Endocr. Disord. 12:13. doi: 10.1186/1472-6823-12-13

Baeza, N., Sanchez, D., Christa, L., Guy-Crotte, O., Vialettes, B., and Figarella, C. (2001). Pancreatitis-Associated Protein (HIP $\forall$ PAP) Gene expression is upregulated in NOD mice pancreas and localized in exocrine tissue during diabetes. Digestion 64, 233-239. doi: 10.1159/000048867

Bartoli, C., Baeza, N., Figarella, C., Pellegrini, I., and Figarella-Branger, D. (1998). Expression of peptide-23/pancreatitis-associated protein and Reg genes in human pituitary and adenomas: comparison with other fetal and adult human tissues. J. Clin. Endocrinol. Metab. 83, 4041-4046. doi: 10.1210/jc.83.11. 4041

Bishnupuri, K. S., Sainathan, S. K., Bishnupuri, K., Leahy, D. R., Luo, Q., Anant, S., et al. (2014). Reg4-induced mitogenesis involves Akt-GSK3beta-beta-CateninTCF-4 signaling in human colorectal cancer. Mol. Carcinog. 53(Suppl. 1), E169-E180. doi: 10.1002/mc.22088

Bluth, M., Mueller, C. M., Pierre, J., Callender, G., Kandil, E., Viterbo, D., et al. (2008). Pancreatic regenerating protein I in chronic pancreatitis and aging: implications for new therapeutic approaches to diabetes. Pancreas 37, 386-395. doi: 10.1097/MPA.0b013e31817f7893

Bluth, M. H., Patel, S. A., Dieckgraefe, B. K., Okamoto, H., and Zenilman, M. E. (2006). Pancreatic regenerating protein (regI) and regI receptor mRNA are upregulated in rat pancreas after induction of acute pancreatitis. World $J$. Gastroenterol. 12, 4511-4516.

Bonjoch, L., Gironella, M., Iovanna, J. L., and Closa, D. (2017). REG3beta modifies cell tumor function by impairing extracellular vesicle uptake. Sci. Rep. 7:3143. doi: 10.1038/s41598-017-03244-4

\section{FUNDING}

Funding support has been provided by the National Science Foundation (NSF, CBET1743367) to ET.

\section{ACKNOWLEDGMENTS}

The authors would like to thank the members of the ET's research group for insightful discussions while preparing the manuscript. The authors apologize to many researchers whose studies could not be cited owing to space limitations.

Borelli, M. I., Stoppiglia, L. F., Rezende, L. F., Flores, L. E., Del Zotto, H., Boschero, A. C., et al. (2005). INGAP-related pentadecapeptide: its modulatory effect upon insulin secretion. Regul. Pept. 131, 97-102. doi: 10.1016/j.regpep.2005.07.003

Bravo-Egana, V., Rosero, S., Molano, R. D., Pileggi, A., Ricordi, C., DominguezBendala, J., et al. (2008). Quantitative differential expression analysis reveals miR-7 as major islet microRNA. Biochem. Biophys. Res. Commun. 366, 922-926. doi: 10.1016/j.bbrc.2007.12.052

Cash, H. L., Whitham, C. V., and Hooper, L. V. (2006). Refolding, purification, and characterization of human and murine RegIII proteins expressed in Escherichia coli. Protein Expr. Purif. 48, 151-159. doi: 10.1016/j.pep.2006.01.014

Cavard, C., Terris, B., Grimber, G., Christa, L., Audard, V., Radenen-Bussiere, B., et al. (2006). Overexpression of regenerating islet-derived 1 alpha and 3 alpha genes in human primary liver tumors with beta-catenin mutations. Oncogene 25, 599-608. doi: 10.1038/sj.onc.1208860

Cerini, C., Peyrot, V., Garnier, C., Duplan, L., Veesler, S., and Le Caer, J. P. (1999). Biophysical characterization of lithostathine. Evidences for a polymeric structure at physiological $\mathrm{pH}$ and a proteolysis mechanism leading to the formation of fibrils. J. Biol. Chem. 274, 22266-22274. doi: 10.1074/jbc.274.32. 22266

Cervello, M., Giannitrapani, L., La Rosa, M., Notarbartolo, M., D’alessandro, N., Virruso, L., et al. (2002). Expression of HIP/PAP mRNA in human hepatoma cell lines. Ann. N. Y. Acad. Sci. 963, 53-58. doi: 10.1111/j.1749-6632.2002. tb04094.x

Christa, L., Pauloin, A., Simon, M. T., Stinnakre, M. G., Fontaine, M. L., Delpal, S., et al. (2000). High expression of the human hepatocarcinoma-intestinepancreas/pancreatic-associated protein (HIP/PAP) gene in the mammary gland of lactating transgenic mice. Secretion into the milk and purification of the HIP/PAP lectin. Eur. J. Biochem. 267, 1665-1671. doi: 10.1046/j.1432-1327. 2000.01159.x

Correa-Medina, M., Bravo-Egana, V., Rosero, S., Ricordi, C., Edlund, H., Diez, J., et al. (2009). MicroRNA miR-7 is preferentially expressed in endocrine cells of the developing and adult human pancreas. Gene Expr. Patterns 9, 193-199. doi: 10.1016/j.gep.2008.12.003

Cox, A. R., Beamish, C. A., Carter, D. E., Arany, E. J., and Hill, D. J. (2015). Cellular mechanisms underlying failed beta cell regeneration in offspring of protein-restricted pregnant mice. Exp. Biol. Med. 238, 1147-1159. doi: 10.1177/ 1535370213493715

Cui, W., De Jesus, K., Zhao, H., Takasawa, S., Shi, B., Srikant, C. B., et al. (2009). Overexpression of Reg3alpha increases cell growth and the levels of cyclin D1 and CDK4 in insulinoma cells. Growth Factors 27, 195-202. doi: 10.1080/ 08977190902863548

Darnaud, M., Dos Santos, A., Gonzalez, P., Augui, S., Lacoste, C., and Desterke, C. (2018). Enteric delivery of regenerating family member 3 alpha alters the intestinal microbiota and controls inflammation in mice with colitis. Gastroenterology 154, 1009-1023.e14. doi: 10.1053/j.gastro.2017.11.003

De Caro, A., Lohse, J., and Sarles, H. (1979). Characterization of a protein isolated from pancreatic calculi of men suffering from chronic calcifying pancreatitis. Biochem. Biophys. Res. Commun. 87, 1176-1182. doi: 10.1016/s0006-291x(79) 80031-5

de la Monte, S. M., Ozturk, M., and Wands, J. R. (1990). Enhanced expression of an exocrine pancreatic protein in Alzheimer's disease and the developing human brain. J. Clin. Invest. 86, 1004-1013. doi: 10.1172/jci114762 
De Reggi, M., Capon, C., Gharib, B., Wieruszeski, J. M., Michel, R., and Fournet, B. (1995). The glycan moiety of human pancreatic lithostathine. Structure characterization and possible pathophysiological implications. Eur. J. Biochem. 230, 503-510. doi: 10.1111/j.1432-1033.1995.0503h.x

De Reggi, M., and Gharib, B. (2001). Protein-X, Pancreatic Stone-, Pancreatic thread-, reg-protein, P19, lithostathine, and now what? Characterization, structural analysis and putative function(s) of the major non-enzymatic protein of pancreatic secretions. Curr. Protein Pept. Sci. 2, 19-42. doi: 10.2174/ 1389203013381233

Dieckgraefe, B. K., Crimmins, D. L., Landt, V., Houchen, C., Anant, S., PorcheSorbet, R., et al. (2002). Expression of the regenerating gene family in inflammatory bowel disease mucosa: reg $\mathrm{I} \alpha$ upregulation, processing, and antiapoptotic activity. J. Investig. Med. 50, 421-434. doi: 10.1136/jim-50-06-02

Downing, S., Zhang, F., Chen, Z., and Tzanakakis, E. S. (2019). MicroRNA7 directly targets Reg1 in pancreatic cells. Am. J. Physiol. Cell Physiol. 317, C366-C374. doi: 10.1152/ajpcell.00013.2019

Du, F., and Yao, Z. W. (2013). The expression patterns of Reg IV gene in normal rat reproduction system. J. Exp. Zool. A Ecol. Genet. Physiol. 319, 32-38. doi: $10.1002 /$ jez.1771

Duplan, L., Michel, B., Boucraut, J., Barthellemy, S., Desplat-Jego, S., Marin, V., et al. (2001). Lithostathine and pancreatitis-associated protein are involved in the very early stages of Alzheimer's disease. Neurobiol. Aging 22, 79-88. doi: 10.1016/s0197-4580(00)00182-2

Dusetti, N. J., Mallo, G. V., Ortiz, E. M., Keim, V., Dagorn, J. C., and Iovanna, J. L. (1996a). Induction of lithostathine/reg mRNA expression by serum from rats with acute pancreatitis and cytokines in pancreatic acinar AR-42J cells. Arch. Biochem. Biophys. 330, 129-132. doi: 10.1006/abbi.1996.0234

Dusetti, N. J., Montalto, G., Ortiz, E., Masciotra, L., Dagorn, J., and Iovanna, J. (1996b). Mechanism of PAP I gene induction during hepatocarcinogenesis: clinical implications. Br. J. Cancer 74, 1767-1775. doi: 10.1038/bjc.1996.628

Ferrara, J. L., Harris, A. C., Greenson, J. K., Braun, T. M., Holler, E., and Teshima, T. (2011). Regenerating islet-derived 3-alpha is a biomarker of gastrointestinal graft-versus-host disease. Blood 118, 6702-6708. doi: 10.1182/blood-2011-08375006

Ferres-Maso, M., Sacilotto, N., Lopez-Rodas, G., Dagorn, J. C., Iovanna, J. L., Closa, D., et al. (2009). PAP1 signaling involves MAPK signal transduction. Cell Mol. Life Sci. 66, 2195-2204. doi: 10.1007/s00018-009-0040-4

Fukui, H., Fujii, S., Takeda, J., Kayahara, T., Sekikawa, A., Nanakin, A., et al. (2004). Expression of Reg I $\alpha$ protein in human gastric cancers. Digestion 69, 177-184. doi: $10.1002 /$ ijc. 24624

Geng, J., Fan, J., Wang, Q., Zhang, X. P., Kang, L., and Li, Q. Y. (2017). Decreased REG1alpha expression suppresses growth, invasion and angiogenesis of bladder cancer. Eur. J. Surg. Oncol. 43, 837-846. doi: 10.1016/j.ejso.2017.01.013

Gerbaud, V., Pignol, D., Loret, E., Bertrand, J. A., Berland, Y., Fontecilla-Camps, J. C., et al. (2000). Mechanism of calcite crystal growth inhibition by the Nterminal undecapeptide of lithostathine. J. Biol. Chem. 275, 1057-1064. doi: 10.1074/jbc.275.2.1057

Gironella, M., Calvo, C., Fernández, A., Closa, D., Iovanna, J. L., Rosello-Catafau, J., et al. (2013). Reg3 $\beta$ deficiency impairs pancreatic tumor growth by skewing macrophage polarization. Cancer Res. 73, 5682-5694. doi: 10.1158/0008-5472. can-12-3057

Graf, R., Schiesser, M., Reding, T., Appenzeller, P., Sun, L. K., Fortunato, F., et al. (2006). Exocrine meets endocrine: pancreatic stone protein and regenerating protein-two sides of the same coin. J. Surg. Res. 133, 113-120. doi: 10.1016/j. jss.2005.09.030

Graf, R., Schiesser, M., Scheele, G. A., Marquardt, K., Frick, T. W., Ammann, R. W., et al. (2001). A family of 16-kDa pancreatic secretory stress proteins form highly organized fibrillar structures upon tryptic activation. J. Biol. Chem. 276, 21028-21038. doi: 10.1074/jbc.m010717200

Graversen, J. H., Lorentsen, R. H., Jacobsen, C., Moestrup, S. K., Sigurskjold, B. W., Thogersen, H. C., et al. (1998). The plasminogen binding site of the C-type lectin tetranectin is located in the carbohydrate recognition domain, and binding is sensitive to both calcium and lysine. J. Biol. Chem. 273, 29241-29246. doi: 10.1074/jbc.273.44.29241

Gross, D. J., Weiss, L., Reibstein, I., Brand, J. V. D., Okamoto, H., Clark, A., et al. (1998). Amelioration of diabetes in nonobese diabetic mice with advanced disease by linomide-induced immunoregulation combined with reg protein treatment. Endocrinology 139, 2369-2374.
Gross, J., Carlson, R., Brauer, A., Margolies, M., Warshaw, A., and Wands, J. (1985). Isolation, characterization, and distribution of an unusual pancreatic human secretory protein. J. Clin. Invest. 76, 2115-2126. doi: 10.1172/jci112216

Grutzmann, R., Foerder, M., Alldinger, I., Staub, E., Brummendorf, T., Ropcke, S., et al. (2003). Gene expression profiles of microdissected pancreatic ductal adenocarcinoma. Virchows Arch. 443, 508-517. doi: 10.1007/s00428-0030884-1

Gurr, W., Yavari, R., Wen, L., Shaw, M., Mora, C., Christa, L., et al. (2002). A Reg family protein is overexpressed in islets from a patient with new-onset type 1 diabetes and acts as T-cell autoantigen in NOD mice. Diabetes Metab. Res. Rev. 51, 339-346. doi: 10.2337/diabetes.51.2.339

Haldipur, P., Dupuis, N., Degos, V., Moniaux, N., Chhor, V., and Rasika, S. (2014). HIP/PAP prevents excitotoxic neuronal death and promotes plasticity. Ann. Clin. Transl. Neurol. 1, 739-754. doi: 10.1002/acn3.127

Hara, K., Fukui, H., Sun, C., Kitayama, Y., Eda, H., Yamasaki, T., et al. (2015). Effect of REG Ialpha protein on angiogenesis in gastric cancer tissues. Oncol. Rep. 33, 2183-2189. doi: 10.3892/or.2015.3878

Hartupee, J. C., Zhang, H., Bonaldo, M. F., Soares, M. B., and Dieckgraefe, B. K. (2001). Isolation and characterization of a cDNA encoding a novel member of the human regenerating protein family: reg IV. Biochim. Biophys. Acta 1518, 287-293. doi: 10.1016/s0167-4781(00)00284-0

Hervieu, V., Christa, L., Gouysse, G., Bouvier, R., Chayvialle, J. A., Brechot, C., et al. (2006). HIP/PAP, a member of the reg family, is expressed in glucagonproducing enteropancreatic endocrine cells and tumors. Hum. Pathol. 37, 1066-1075. doi: 10.1016/j.humpath.2006.03.005

Ho, M. R., Lou, Y. C., Lin, W. C., Lyu, P. C., Huang, W. N., and Chen, C. (2006). Human pancreatitis-associated protein forms fibrillar aggregates with a native-like conformation. J. Biol. Chem. 281, 33566-33576. doi: 10.1074/jbc. m604513200

Ho, M. R., Lou, Y. C., Wei, S. Y., Luo, S. C., Lin, W. C., Lyu, P. C., et al. (2010). Human RegIV protein adopts a typical C-type lectin fold but binds mannan with two calcium-independent sites. J. Mol. Biol. 402, 682-695. doi: 10.1016/j. jmb.2010.07.061

Hou, W. R., Xie, S. N., Wang, H. J., Su, Y. Y., Lu, J. L., Li, L. L., et al. (2011). Intramuscular delivery of a naked DNA plasmid encoding proinsulin and pancreatic regenerating III protein ameliorates type 1 diabetes mellitus. Pharmacol. Res. 63, 320-327. doi: 10.1016/j.phrs.2010.12.009

Iovanna, J., Frigerio, J. M., Dusetti, N., Ramare, F., Raibaud, P., and Dagorn, J. C. (1993). Lithostathine, an inhibitor of $\mathrm{CaCO} 3$ crystal growth in pancreatic juice, induces bacterial aggregation. Pancreas 8, 597-601. doi: 10.1097/00006676199309000-00011

Jiang, H., Tian, K.-W., Zhang, F., Wang, B., and Han, S. (2016). Reg2, A downstream signaling protein in the ciliary neurotrophic factor survival pathway, alleviates experimental autoimmune encephalomyelitis. Front. Neuroanat. 10:50. doi: 10.3389/fnana.2016.00050

Jing, D., Kehoe, D. E., and Tzanakakis, E. S. (2010). Expression of Reg family proteins in embryonic stem cells and its modulation by Wnt/beta-catenin signaling. Stem Cells Dev. 19, 1307-1319. doi: 10.1089/scd.2009.0398

Kadowaki, Y., Ishihara, S., Miyaoka, Y., Rumi, M. A., Sato, H., and Kazumori, H. (2002). Reg protein is overexpressed in gastric cancer cells, where it activates a signal transduction pathway that converges on ERK1/2 to stimulate growth. FEBS Lett. 530, 59-64. doi: 10.1016/s0014-5793(02)03398-7

Katsuno, Y., Ehata, S., Yashiro, M., Yanagihara, K., Hirakawa, K., and Miyazono, K. (2012). Coordinated expression of REG4 and aldehyde dehydrogenase 1 regulating tumourigenic capacity of diffuse-type gastric carcinoma-initiating cells is inhibited by TGF- $\beta$. J. Pathol. 228, 391-404. doi: 10.1002/path.4020

Kawasaki, Y., Matsumura, K., Miyamoto, M., Tsuji, S., Okuno, M., Suda, S., et al. (2015). REG4 is a transcriptional target of GATA6 and is essential for colorectal tumorigenesis. Sci. Rep. 5:14291. doi: 10.1038/srep14291

Keilbaugh, S. A., Shin, M. E., Banchereau, R. F., McVay, L. D., Boyko, N., Artis, D., et al. (2005). Activation of RegIIIbeta/gamma and interferon gamma expression in the intestinal tract of SCID mice: an innate response to bacterial colonisation of the gut. Gut 54, 623-629. doi: 10.1136/gut.2004.056028

Kim, B. T., Kitagawa, H., Tamura, J., Saito, T., Kusche-Gullberg, M., Lindahl, U., et al. (2001). Human tumor suppressor EXT gene family members EXTL1 and EXTL3 encode alpha 1,4- N-acetylglucosaminyltransferases that likely are involved in heparan sulfate/ heparin biosynthesis. Proc. Natl. Acad. Sci. U.S.A. 98, 7176-7181. doi: 10.1073/pnas.131188498 
Kimura, T., Fukui, H., Sekikawa, A., Yamagishi, H., Ichikawa, K., and Tomita, S. (2009). Involvement of REG Ialpha protein in the regeneration of ductal epithelial cells in the minor salivary glands of patients with Sjogren's syndrome. Clin. Exp. Immunol. 155, 16-20. doi: 10.1111/j.1365-2249.2008.03806.x

Kleeff, J., Korc, M., Apte, M., La Vecchia, C., Johnson, C. D., Biankin, A. V., et al. (2016). Pancreatic cancer. Nat. Rev. Dis. Primers 2:16022. doi: 10.1038/nrdp. 2016.22

Kobayashi, S., Akiyama, T., Nata, K., Abe, M., Tajima, M., Shervani, N. J., et al. (2000). Identification of a receptor for reg (regenerating gene) protein, a pancreatic beta-cell regeneration factor. J. Biol. Chem. 275, 10723-10726. doi: 10.1074/jbc.275.15.10723

Konishi, H., Matsumoto, S., Namikawa, K., and Kiyama, H. (2013). N-terminal cleaved pancreatitis-associated protein-III (PAP-III) serves as a scaffold for neurites and promotes neurite outgrowth. J. Biol. Chem. 288, 10205-10213. doi: 10.1074/jbc.M112.395301

Kuniyasu, H., Oue, N., Sasahira, T., Yi, L., Moriwaka, Y., Shimomoto, T., et al. (2009). Reg IV enhances peritoneal metastasis in gastric carcinomas. Cell Prolif. 42, 110-121. doi: 10.1111/j.1365-2184.2008.00577.x

LaFonte, M. W., Stanek, A., Mueller, C., Zenilman, M. E., Sugawara, A., Alfonso, A. E., et al. (2013). Identification of Reg1 as a novel stellate cell activator in regenerating pancreas. J. Am. Coll. Surg. 217:S18.

Lai, Y., Li, D., Li, C., Muehleisen, B., Radek, K. A., Park, H. J., et al. (2012). The antimicrobial protein REG3A regulates keratinocyte proliferation and differentiation after skin injury. Immunity 37, 74-84. doi: 10.1016/j.immuni. 2012.04.010

Lasserre, C., Colnot, C., Bréchot, C., and Poirier, F. (1999). HIP/PAP gene, encoding a C-type lectin overexpressed in primary liver cancer, is expressed in nervous system as well as in intestine and pancreas of the postimplantation mouse embryo. Am. J. Pathol. 154, 1601-1610. doi: 10.1016/s0002-9440(10) 65413-2

Lasserre, C., Simon, M. T., Ishikawa, H., Diriong, S., Nguyen, V. C., Christa, L., et al. (1994). Structural organization and chromosomal localization of a human gene (HIP/PAP) encoding a C-type lectin overexpressed in primary liver cancer. Eur. J. Biochem. 224, 29-38. doi: 10.1111/j.1432-1033.1994.tb19991.x

Lee, B. I., Mustafi, D., Cho, W., and Nakagawa, Y. (2003). Characterization of calcium binding properties of lithostathine. J. Biol. Inorg. Chem. 8, 341-347. doi: 10.1007/s00775-002-0421-8

Legoffic, A., Calvo, E., Cano, C., Folch-Puy, E., Barthet, M., and Delpero, J. R. (2009). The reg4 gene, amplified in the early stages of pancreatic cancer development, is a promising therapeutic target. PLoS One 4:e7495. doi: 10.1371/ journal.pone.0007495

Lehotzky, R. E., Partch, C. L., Mukherjee, S., Cash, H. L., Goldman, W. E., Gardner, K. H., et al. (2010). Molecular basis for peptidoglycan recognition by a bactericidal lectin. Proc. Natl. Acad. Sci. U.S.A. 107, 7722-7727. doi: 10.1073/ pnas.0909449107

Li, A., Crimmins, D. L., Luo, Q., Hartupee, J., Landt, Y., Ladenson, J. H., et al. (2003). Expression of a novel regenerating gene product, Reg IV, by high density fermentation in Pichia pastoris: production, purification, and characterization. Protein Expr. Purif. 31, 197-206. doi: 10.1016/s1046-5928(03)00164-5

Li, B., Wang, X., and Liu, J. L. (2010). Pancreatic acinar-specific overexpression of Reg2 gene offered no protection against either experimental diabetes or pancreatitis in mice. Am. J. Physiol. Gastrointest. Liver Physiol. 299, G413-G421. doi: 10.1152/ajpgi.00500.2009

Li, Q., Li, B., Miao, X., Ramgattie, C., Gao, Z. H., and Liu, J. L. (2017). Reg2 expression is required for pancreatic islet compensation in response to aging and high-fat diet-induced obesity. Endocrinology 158, 1634-1644. doi: 10.1210/ en.2016-1551

Li, Q., Liu, J. L., and Gao, Z. H. (2016a). REG3beta plays a key role in IL17RA protumoral effect-letter. Cancer Res. 76:2050. doi: 10.1158/0008-5472.can-152961

Li, Q., Wang, H., Nwilati, K., Zogopoulos, G., Gui, X.-Y., Shao, Q., et al. (2016b). Reg proteins promote acinar-to-ductal metaplasia and act as novel diagnostic and prognostic markers in pancreatic ductal adenocarcinoma. Oncotarget 7 , 77838-77853. doi: 10.18632/oncotarget.12834

Lieu, H. T., Batteux, F., Simon, M. T., Cortes, A., Nicco, C., Zavala, F., et al. (2005). HIP/PAP accelerates liver regeneration and protects against acetaminophen injury in mice. Hepatology 42, 618-626. doi: 10.1002/hep. 20845
Lieu, H. T., Simon, M. T., Nguyen-Khoa, T., Kebede, M., Cortes, A., and Tebar, L. (2006). Reg2 inactivation increases sensitivity to Fas hepatotoxicity and delays liver regeneration post-hepatectomy in mice. Hepatology 44, 1452-1464. doi: 10.1002/hep. 21434

Liu, L., Liu, J. L., and Srikant, C. B. (2010). Reg2 protects mouse insulinoma cells from streptozotocin-induced mitochondrial disruption and apoptosis. Growth Factors 28, 370-378. doi: 10.3109/08977194.2010.504721

Liu, X., Wang, J., Wang, H., Yin, G., Liu, Y., Lei, X., et al. (2015). REG3A accelerates pancreatic cancer cell growth under IL-6-associated inflammatory condition: involvement of a REG3A-JAK2/STAT3 positive feedback loop. Cancer Lett. 362, 45-60. doi: 10.1016/j.canlet.2015.03.014

Livesey, F. J., O’Brien, J. A., Li, M., Smith, A. G., Murphy, L. J., and Hunt, S. P. (1997). A schwann cell mitogen accompanying regeneration of motor neurons. Nature 390, 614-618. doi: 10.1038/37615

Loncle, C., Bonjoch, L., Folch-Puy, E., Lopez-Millan, M. B., Lac, S., and Molejon, M. I. (2015). IL17 functions through the novel REG3 $\beta$-JAK2-STAT3 inflammatory pathway to promote the transition from chronic pancreatitis to pancreatic cancer. Cancer Res. 75, 4852-4862. doi: 10.1158/0008-5472.CAN15-0896

Loncle, C., Bonjoch, L., Folch-Puy, E., Lopez-Millan, M. B., Lac, S., and Molejon, M. I. (2016). REG3beta plays a key role in IL17RA protumoral effect-response. Cancer Res. 76:2051. doi: 10.1158/0008-5472.can-15-3355

Ma, X., Wu, D., Zhou, S., Wan, F., Liu, H., Xu, X., et al. (2016). The pancreatic cancer secreted REG4 promotes macrophage polarization to M2 through EGFR/AKT/CREB pathway. Oncol. Rep. 35, 189-196. doi: 10.3892/or.2015. 4357

Mally, M. I., Otonkoski, T., Lopez, A. D., and Hayek, A. (1994). Developmental gene expression in the human fetal pancreas. Pediatr. Res. 36, 537-544. doi: 10.1203/00006450-199410000-00022

Martin, B., Mueller, C. M., Pierre, J., Callender, G., and Kandil, E. (2008). Pancreatic regenerating protein $\mathrm{I}$ in chronic pancreatitis and aging: implications for new therapeutic approaches to diabetes. Pancreas 37, 386-395. doi: 10.1097/MPA. 0b013e31817f7893

März-Weiss, P., Kunz, D., Bimmler, D., Berkemeier, C., Özbek, S., and Dimitriades-Schmutz, B. (2011). Expression of pancreatitis-associated protein after traumatic brain injury: a mechanism potentially contributing to neuroprotection in human brain. Cell Mol. Neurobiol. 31, 1141-1149. doi: 10. 1007/s10571-011-9715-0

Matsumoto, S., Konishi, H., Maeda, R., Kiryu-Seo, S., and Kiyama, H. (2012). Expression analysis of the regenerating gene (Reg) family members Reg-III $\beta$ and Reg-III $\gamma$ in the mouse during development. J. Comp. Neurol. 520, 479-494. doi: 10.1002/cne.22705

Michael, Z. E., Tuchman, D., Zheng, Q., Levine, J., and Delany, H. (2000). Comparison of reg I and reg III levels during acute pancreatitis in the rat. Ann. Surg. 232, 646-652. doi: 10.1097/00000658-200011000-00005

Michael, Z. M. E., Magnuson, T. M., Swinson, K., Egan, J., Perfetti, R., and Shuldiner, A. R. (1996). Pancreatic thread protein is mitogenic to pancreaticderived cells in culture. Gastroenterology 110, 1208-1214. doi: 10.1053/gast. 1996.v110.pm8613011

Minamiya, Y., Kawai, H., Saito, H., Ito, M., Hosono, Y., Motoyama, S., et al. (2008). REG1A expression is an independent factor predictive of poor prognosis in patients with non-small cell lung cancer. Lung Cancer 60, 98-104. doi: 10.1016/j.lungcan.2007.09.012

Mitani, Y., Oue, N., Matsumura, S., Yoshida, K., Noguchi, T., Ito, M., et al. (2007). Reg IV is a serum biomarker for gastric cancer patients and predicts response to 5-fluorouracil-based chemotherapy. Oncogene 26, 4383-4393. doi: 10.1038/ sj.onc. 1210215

Mizuno, K., Irie, S., and Sato, T. A. (2001). Overexpression of EXTL3/EXTR1 enhances NF-kappaB activity induced by TNF-alpha. Cell. Signal. 13, 125-130. doi: 10.1016/s0898-6568(00)00144-3

Moniaux, N., Song, H., Darnaud, M., Garbin, K., Gigou, M., and Mitchell, C. (2011). Human hepatocarcinoma-intestine-pancreas/pancreatitis-associated protein cures fas-induced acute liver failure in mice by attenuating free-radical damage in injured livers. Hepatology 53, 618-627. doi: 10.1002/hep.24087

Moussaed, M., Huc-Brandt, S., Cubedo, N., Silhol, M., Murat, S., Lebart, M. C., et al. (2018). Regenerating islet-derived $1 \alpha$ (REG-1 $\alpha$ ) protein increases tau phosphorylation in cell and animal models of tauopathies. Neurobiol. Dis. 119, 136-148. doi: 10.1016/j.nbd.2018.07.029 
Mueller, C. M., Zhang, H., and Zenilman, M. E. (2008). Pancreatic reg I binds MKP1 and regulates cyclin D in pancreatic-derived cells. J. Surg. Res. 150, 137-143. doi: 10.1016/j.jss.2008.03.047

Mukherjee, S., Zheng, H., Derebe, M. G., Callenberg, K. M., Partch, C. L., Rollins, D., et al. (2014). Antibacterial membrane attack by a pore-forming intestinal C-type lectin. Nature 505, 103-107. doi: 10.1038/nature12729

Naito, Y., Oue, N., Hinoi, T., Sakamoto, N., Sentani, K., Ohdan, H., et al. (2012). Reg IV is a direct target of intestinal transcriptional factor CDX2 in gastric cancer. PLoS One 7:e47545. doi: 10.1371/journal.pone.0047545

Namikawa, K., Fukushima, M., Murakami, K., Suzuki, A., Takasawa, S., Okamoto, H., et al. (2005). Expression of Reg/PAP family members during motor nerve regeneration in rat. Biochem. Biophys. Res. Commun. 332, 126-134. doi: 10. 1016/j.bbrc.2005.04.105

Namikawa, K., Okamoto, T., Suzuki, A., Konishi, H., and Kiyama, H. (2006). Pancreatitis-associated protein-III is a novel macrophage chemoattractant implicated in nerve regeneration. J. Neurosci. 26, 7460-7467. doi: 10.1523/ jneurosci.0023-06.2006

Nanakin, A., Fukui, H., Fujii, S., Sekikawa, A., Kanda, N., Hisatsune, H., et al. (2007). Expression of the REG IV gene in ulcerative colitis. Lab. Invest. 87, 304-314. doi: 10.1038/labinvest.3700507

Ochiai, K., Kaneko, K., Kitagawa, M., Ando, H., and Hayakawa, T. (2004). Activated pancreatic enzyme and pancreatic stone protein (PSP/reg) in bile of patients with pancreaticobiliary maljunction/choledochal cysts. Dig. Dis. Sci. 49, 1953-1956. doi: 10.1007/s10620-004-9599-7

Ogawa, H., Fukushima, K., Naito, H., Funayama, Y., Unno, M., Takahashi, K., et al. (2003). Increased expression of HIP/PAP and regenerating gene III in human inflammatory bowel disease and a murine bacterial reconstitution model. Inflamm. Bowel Dis. 9, 162-170. doi: 10.1097/00054725-200305000-00003

Okamoto, H. (1999). The Reg gene family and Reg proteins: with special attention to the regeneration of pancreatic $\beta$-cells. J. Hepatobiliary Pancreat. Sci. 6, 254-262. doi: 10.1007/s005340050115

Okamoto, K., Fujimori, T., Yamaguchi, T., Ichikawa, K., Tomita, S., Sugai, T., et al. (2013). Overexpression of regenerating gene $\mathrm{I} \alpha$ appears to reflect aberration of crypt cell compartmentalization in sessile serrated adenoma/polyps of the colon. Diagn. Pathol. 8:187. doi: 10.1186/1746-1596-8-187

Ose, T., Kadowaki, Y., Fukuhara, H., Kazumori, H., Ishihara, S., Udagawa, J., et al. (2007). Reg I-knockout mice reveal its role in regulation of cell growth that is required in generation and maintenance of the villous structure of small intestine. Oncogene 26, 349-359. doi: 10.1038/sj.onc.1209799

Osman, N. M., Kagohashi, Y., Udagawa, J., and Otani, H. (2003). Alpha1,4$\mathrm{N}$-acetylglucosaminyltransferase encoding gene EXTL3 expression pattern in mouse adult and developing tissues with special attention to the pancreas. Anat. Embryol. 207, 333-341. doi: 10.1007/s00429-003-0348-Z

Oue, N., Mitani, Y., Aung, P. P., Sakakura, C., Takeshima, Y., Kaneko, M., et al. (2005). Expression and localization of Reg IV in human neoplastic and non-neoplastic tissues: reg IV expression is associated with intestinal and neuroendocrine differentiation in gastric adenocarcinoma. J. Pathol. 207, 185-198. doi: 10.1002/path.1827

Ozturk, M., de la Monte, S. M., Gross, J., and Wands, J. R. (1989). Elevated levels of an exocrine pancreatic secretory protein in Alzheimer disease brain. Proc. Natl. Acad. Sci. U.S.A 86, 419-423. doi: 10.1073/pnas.86.2.419

Parikh, A., Stephan, A. F., and Tzanakakis, E. S. (2012). Regenerating proteins and their expression, regulation and signaling. Biomol. Concepts 3, 57-70.

Park, J. Y., Kim, S. A., Chung, J. W., Bang, S., Park, S. W., Paik, Y. K., et al. (2011). Proteomic analysis of pancreatic juice for the identification of biomarkers of pancreatic cancer. J. Cancer Res. Clin. Oncol. 137, 1229-1238. doi: 10.1007/ s00432-011-0992-2

Perfetti, R., Egan, J. M., Zenilman, M. E., and Shuldiner, A. R. (1996a). Differential expression of reg-I and reg-II genes during aging in the normal mouse. J. Gerontol. 51A, B308-B315.

Perfetti, R., Raygada, M., Wang, Y., Zenilman, M. E., Egan, J. M., Denno, K. M., et al. (1996b). Regenerating (reg) and insulin genes are expressed in prepancreatic mouse embryos. J. Mol. Endocrinol. 17, 79-88. doi: 10.1677/jme. 0.0170079

Peterson, K. M., Guo, X., Elkahloun, A. G., Mondal, D., Bardhan, P. K., Sugawara, A., et al. (2011). The expression of REG $1 \mathrm{~A}$ and REG $1 \mathrm{~B}$ is increased during acute amebic colitis. Parasitol. Int. 60, 296-300. doi: 10.1016/j.parint.2011. 04.005
Planas, R., Pujol-Autonell, I., Ruiz, E., Montraveta, M., Cabre, E., and LucasMartin, A. (2011). Regenerating gene Ialpha is a biomarker for diagnosis and monitoring of celiac disease: a preliminary study. Transl. Res. 158, 140-145. doi: 10.1016/j.trsl.2011.04.004

Porterfield, M., Zhao, P., Han, H., Cunningham, J., Aoki, K., Von Hoff, D. D., et al. (2014). Discrimination between adenocarcinoma and normal pancreatic ductal fluid by proteomic and glycomic analysis. J. Proteome Res. 13, 395-407. doi: $10.1021 / \mathrm{pr} 400422 \mathrm{~g}$

Qiu, L., List, E. O., and Kopchick, J. J. (2005). Differentially expressed proteins in the pancreas of diet-induced diabetic mice. Mol. Cell. Proteomics 4, 1311-1318. doi: 10.1074/mcp.m500016-mcp200

Qiu, Y.-S., Liao, G. J., and Jiang, N. N. (2017). DNA methylation-mediated silencing of regenerating Protein 1 Alpha (REG1A) affects gastric cancer prognosis. Med. Sci. Monit. 23, 5834-5843. doi: 10.12659/msm.904706

Qiu, Y. S., Liao, G. J., and Jiang, N. N. (2018). REG3A overexpression suppresses gastric cancer cell invasion, proliferation and promotes apoptosis through PI3K/Akt signaling pathway. Int. J. Mol. Med. 41, 3167-3174. doi: 10.3892/ ijmm.2018.3520

Radon, T. P., Massat, N. J., Jones, R., Alrawashdeh, W., Dumartin, L., Ennis, D., et al. (2015). Identification of a three-biomarker panel in urine for early detection of pancreatic adenocarcinoma. Clin. Cancer Res. 21, 3512-3521. doi: 10.1158/1078-0432.CCR-14-2467

Rafaeloff, R., Pittenger, G. L., Barlow, S. W., Qin, X. F., Yan, B., and Rosenberg, L. (1997). Cloning and sequencing of the pancreatic islet neogenesis associated protein (INGAP) gene and its expression in islet neogenesis in hamsters. J. Clin. Invest. 99, 2100-2109. doi: 10.1172/jci 119383

Sala, P., Torrinhas, R. S., Fonseca, D. C., Heymsfield, S., Giannella-Neto, D., and Waitzberg, D. L. (2017). Type 2 diabetes remission after Roux-en-Y gastric bypass: evidence for increased expression of jejunal genes encoding regenerating pancreatic islet-derived proteins as a potential mechanism. Obes. Surg. 27, 1123-1127. doi: 10.1007/s11695-017-2602-0

Sasaki, N., Sachs, N., Wiebrands, K., Ellenbroek, S. I., Fumagalli, A., and Lyubimova, A. (2016). Reg4+ deep crypt secretory cells function as epithelial niche for Lgr5+ stem cells in colon. Proc. Natl. Acad. Sci. U.S.A. 113, E5399E5407. doi: 10.1073/pnas.1607327113

Sasaki, Y., Minamiya, Y., Takahashi, N., Nakagawa, T., Katayose, Y., Ito, A., et al. (2008). REG1A expression is an independent factor predictive of poor prognosis in patients with breast cancer. Ann. Surg. Oncol. 15, 3244-3251. doi: 10.1245/ s10434-008-0137-2

Sato, Y., Motoyama, S., Nanjo, H., Ito, S., Yoshino, K., and Sasaki, T. (2013). REG1A expression status suggests chemosensitivity among advanced thoracic esophageal squamous cell carcinoma patients treated with esophagectomy followed by adjuvant chemotherapy. Ann. Surg. Oncol. 20, 3044-3051. doi: 10.1245/s10434-013-2983-9

Satomura, Y., Sawabu, N., Ohta, H., Watanabe, H., Yamakawa, O., Motoo, Y., et al. (1993). The immunohistochemical evaluation of PSP $\forall$ reg-proteinin normal and diseased human pancreatic tissues. Int. J. Pancreatol. 13, $59-67$.

Sehnal, D., Deshpande, M., Vařeková, R. S., Mir, S., Berka, K., Midlik, A., et al. (2017). LiteMol suite: interactive web-based visualization of large-scale macromolecular structure data. Nat. Methods 14, 1121-1122. doi: 10.1038/ nmeth.4499

Sekikawa, A., Fukui, H., Fujii, S., Takeda, J., Nanakin, A., and Hisatsune, H. (2005). REG I $\alpha$ protein may function as a trophic and/or anti-apoptotic factor in the development of gastric cancer. Gastroenterology 128, 642-653. doi: 10.1053/j. gastro.2004.12.045

Sekikawa, A., Fukui, H., Suzuki, K., Karibe, T., Fujii, S., Ichikawa, K., et al. (2010). Involvement of the IL-22/REG I $\alpha$ axis in ulcerative colitis. Lab. Invest. 90, 496-505. doi: 10.1038/labinvest.2009.147

Simon, M. T., Pauloin, A., Normand, G., Lieu, H. T., Mouly, H., Pivert, G., et al. (2003). HIP/PAP stimulates liver regeneration after partial hepatectomy and combines mitogenic and anti-apoptotic functions through the PKA signaling pathway. FASEB J. 17, 1441-1450. doi: 10.1096/fj.021013com

Takasawa, S., Ikeda, T., Akiyama, T., Nata, K., Nakagawa, K., Shervani, N. J., et al. (2006). Cyclin D1 activation through ATF-2 in Reg-induced pancreatic beta-cell regeneration. FEBS Lett. 580, 585-591. doi: 10.1016/j.febslet.2005.12.070 
Takehara, A., Eguchi, H., Ohigashi, H., Ishikawa, O., Kasugai, T., and Hosokawa, M. (2006). Novel tumor marker REG4 detected in serum of patients with resectable pancreatic cancer and feasibility for antibody therapy targeting REG4. Cancer Sci. 97, 1191-1197. doi: 10.1111/j.1349-7006.2006.00297.x

Tanaka, H., Fukui, H., Fujii, S., Sekikawa, A., Yamagishi, H., Ichikawa, K., et al. (2011). Immunohistochemical analysis of REG Ialpha expression in ulcerative colitis-associated neoplastic lesions. Digestion 83, 204-209. doi: 10. $1159 / 000321808$

Tao, H. Q., He, X. J., Ma, Y. Y., Wang, H. J., Xia, Y. J., Ye, Z. Y., et al. (2011). Evaluation of REG4 for early diagnosis and prognosis of gastric cancer. Hum. Pathol. 42, 1401-1409. doi: 10.1016/j.humpath.2010.08.023

Tebar, L., Geranton, S., Parsons-Perez, C., Fisher, A., Bayne, R., Smith, A., et al. (2008). Deletion of the mouse RegIII $\beta$ (Reg2) gene disrupts ciliary neurotrophic factor signaling and delays myelination of mouse cranial motor neurons. Proc. Natl. Acad. Sci. U.S.A. 105, 11400-11405. doi: 10.1073/pnas.0711978105

Terazono, K., Yamamoto, H., Takasawa, S., Shiga, K., Yonemura, Y., Tochino, Y., et al. (1988). A novel gene activated in regenerating islets. J. Biol. Chem. 263, 2111-2114.

Tohma, Y., Dohi, Y., Shobatake, R., Uchiyama, T., Takeda, M., Takasawa, S., et al. (2017). Reg gene expression in periosteum after fracture and its in vitro induction triggered by IL-6. Int. J. Mol. Sci. 18:E2257. doi: 10.3390/ ijms18112257

Tsuchida, C., Sakuramoto-Tsuchida, S., Taked, M., Itaya-Hironaka, A., Yamauchi, A., and Misu, M. (2017). Expression of REG family genes in human inflammatory bowel diseases and its regulation. Biochem. Biophys. Rep. 12, 198-205. doi: 10.1016/j.bbrep.2017.10.003

Unno, M., Nata, K., Noguchi, N., Narushima, Y., Akiyama, T., Ikeda, T., et al. (2002). Production and characterization of Reg knockout mice: reduced proliferation of pancreatic beta-cells in Reg knockout mice. Diabetes Metab. Res. Rev. 51(Suppl. 3), S478-S483.

Vaishnava, S., Yamamoto, M., Severson, K. M., Ruhn, K. A., Yu, X., and Koren, O. (2011). The antibacterial lectin RegIIIgamma promotes the spatial segregation of microbiota and host in the intestine. Science 334, 255-258. doi: 10.1126/ science. 1209791

van Ampting, M. T., Loonen, L. M., Schonewille, A. J., Konings, I., Vink, C., Iovanna, J., et al. (2012). Intestinally secreted C-type lectin Reg3b attenuates salmonellosis but not listeriosis in mice. Infect. Immun. 80, 1115-1120. doi: 10.1128/IAI.06165-11

van Beelen Granlund, A., Ostvik, A. E., Brenna, O., Torp, S. H., Gustafsson, B. I., and Sandvik, A. K. (2013). REG gene expression in inflamed and healthy colon mucosa explored by in situ hybridisation. Cell Tissue Res. 352, 639-646. doi: 10.1007/s00441-013-1592-z

Vanderlaag, K., Wang, W., Fayadat-Dilman, L., Wagner, J., Bald, L., Grein, J., et al. (2012). Regenerating islet-derived family member, 4 modulates multiple receptor tyrosine kinases and mediators of drug resistance in cancer. Int. J. Cancer 130, 1251-1263. doi: 10.1002/ijc.26089

Violette, S., Festor, E., Pandrea-Vasile, I., Mitchell, V., Adida, C., Dussaulx, E., et al. (2003). Reg IV, a new member of the regenerating gene family, is overexpressed in colorectal carcinomas. Int. J. Cancer 103, 185-193. doi: 10.1002/ijc. 10788

Viterbo, D., Callender, G. E., DiMaio, T., Mueller, C. M., and Smith-Norowitz, T. (2009). Administration of Anti-Reg I and Anti-PAPII antibodies worsens pancreatitis. J. Pancreas 10, 15-23.

Viterbo, D., Zenilman, M. E., and Bluth, M. H. (2010). Comparison of His and GST tagged versions of recombinant pancreatitis associated protein 2 in modulation of inflammatory responses. Inflamm. Res. 59, 827-835. doi: 10.1007/s00011010-0194-4

Wang, H., Hu, L., Zang, M., Zhang, B., Duan, Y., and Fan, Z. (2016). REG4 promotes peritoneal metastasis of gastric cancer through GPR37. Oncotarget 7, 27874-27888. doi: 10.18632/oncotarget.8442

Wang, J., Koyota, S., Zhou, X., Ueno, Y., Ma, L., Kawagoe, M., et al. (2009). Expression and localization of regenerating gene $\mathrm{I}$ in a rat liver regeneration model. Biochem. Biophys. Res. Commun. 380, 472-477. doi: 10.1016/j.bbrc.2009. 01.126
Wang, L., Fouts, D. E., Stärkel, P., Hartmann, P., Chen, P., Llorente, C., et al. (2016). Intestinal REG3 lectins protect against alcoholic steatohepatitis by reducing mucosa-associated microbiota and preventing bacterial translocation. Cell Host Microbe 19, 227-239. doi: 10.1016/j.chom.2016. 01.003

Wang, Y., Jacovetti, C., Li, B., Siddique, T., Xiong, X., Yin, H., et al. (2011). Coordinated age-dependent and pancreatic-specific expression of mouse Reg2Reg3alpha, and Reg3beta genes. Growth Factors 29, 72-81. doi: 10.3109/ 08977194.2011 .562866

Watanabe, T., Yonekura, H., Terazono, K., Yamamoto, H., and Okamoto, H. (1990). Complete nucleotide sequence of human reg gene and its expression in normal and tumoral tissues. The reg protein, pancreatic stone protein, and pancreatic thread protein are one and the same product of the gene. J. Biol. Chem. 265, 7432-7439.

Watanabe, T., Yonemura, Y., Yonekura, H., Suzuki, Y., Miyashita, H., Sugiyama, K., et al. (1994). Pancreatic beta-cell replication and amelioration of surgical diabetes by Reg protein. Proc. Natl. Acad. Sci. U.S.A. 91, 3589-3592. doi: 10.1073/pnas.91.9.3589

Xiong, X., Wang, X., Li, B., Chowdhury, S., Lu, Y., Srikant, C. B., et al. (2011). Pancreatic islet-specific overexpression of Reg $3 \beta$ protein induced the expression of pro-islet genes and protected the mice against streptozotocininduced diabetes mellitus. Am. J. Physiol. Endocrinol. Metab. 300, E669-E680.

Yang, J., Li, L., Raptis, D., Li, X., Li, F., Chen, B., et al. (2015). Pancreatic stone protein/regenerating protein (PSP/reg): a novel secreted protein up-regulated in type 2 diabetes mellitus. Endocrine 48, 856-862. doi: 10.1007/s12020-0140427-3

Yuan, R.-H., Jeng, Y.-M., Chen, H.-L., Hsieh, F.-J., Yang, C.-Y., Lee, P.-H., et al. (2005). Opposite roles of human pancreatitis-associated protein and REG1A expression in hepatocellular carcinoma: association of pancreatitisassociated protein expression with low-stage hepatocellular carcinoma, $\beta$ catenin mutation, and favorable prognosis. Clin. Cancer Res. 11, 2568-2575. doi: 10.1158/1078-0432.ccr-04-2039

Zelensky, A. N., and Gready, J. E. (2005). The C-type lectin-like domain superfamily. FEBS J. 272, 6179-6217. doi: 10.1111/j.1742-4658.2005. 05031.x

Zhao, D., Kim, Y. H., Jeong, S., Greenson, J. K., Chaudhry, M. S., and Hoepting, M. (2018). Survival signal REG3alpha prevents crypt apoptosis to control acute gastrointestinal graft-versus-host disease. J. Clin. Invest. 128, 4970-4979. doi: 10.1172/JCI99261

Zheng, Y., Valdez, P. A., Danilenko, D. M., Hu, Y., Sa, S. M., Gong, Q., et al. (2008). Interleukin-22 mediates early host defense against attaching and effacing bacterial pathogens. Nat. Med. 14, 282-289. doi: 10.1038/ nm1720

Zhou, L., Zhang, R., Wang, L., Shen, S., Okamoto, H., Sugawara, A., et al. (2010). Upregulation of REG Ialpha accelerates tumor progression in pancreatic cancer with diabetes. Int. J. Cancer 127, 1795-1803.doi:10.1002/ijc. 25188

Zhu, X., Han, Y., Yuan, C., Tu, W., Qiu, G., Lu, S., et al. (2015). Overexpression of Reg4, alone or combined with MMP-7 overexpression, is predictive of poor prognosis in colorectal cancer. Oncol. Rep. 33, 320-328. doi: 10.3892/or.2014. 3559

Conflict of Interest: The authors declare that the research was conducted in the absence of any commercial or financial relationships that could be construed as a potential conflict of interest.

Copyright (c) 2019 Chen, Downing and Tzanakakis. This is an open-access article distributed under the terms of the Creative Commons Attribution License (CC BY). The use, distribution or reproduction in other forums is permitted, provided the original author(s) and the copyright owner(s) are credited and that the original publication in this journal is cited, in accordance with accepted academic practice. No use, distribution or reproduction is permitted which does not comply with these terms. 